PNL-10788

UC-702

\title{
The Role of Plants and Animals in Isolation Barriers at Hanford, Washington
}

\author{
S. O. Link \\ L. L. Cadwell \\ K. L. Petersen \\ M. R. Sackschewsky \\ D. S. Landeen
}

September 1995

Prepared for the U.S. Department of Energy under Contract DE-AC06-76RLO 1830

Pacific Northwest Laboratory

Richland, Washington 99352 


\section{DISCLAIMER}

Portions of this document may be illegible in electronic image products. Images are produced from the best available original document. 



\section{Summary}

The Hanford Site Surface Barrier Development Program was organized in 1985 to test the effectiveness of various barrier designs in minimizing the effects of water infiltration; plant, animal, and human intrusion; and wind and water erosion on buried wastes, and in minimizing the emanation of noxious gases. Plants will serve to minimize drainage and erosion, but present the potential for growing roots into wastes. Animals burrow holes into the soil, and the burrow holes could allow water to preferentially drain into the waste. They also bring soil to the surface which, if wastes are incorporated, could present a risk for the dispersion of wastes into the environment. This report reviews work done to assess the role of plants and animals in isolation barriers at Hanford. It also reviews work done to understand the potential effects from climate change on the plants and animals that may inhabit barriers in the future.

Plant studies have been done on community analysis, root characteristics, water balance, and water and wind erosion. Community analyses are reviewed in the context of native plants, invasive aliens, community dynamics, and revegetation efforts. Roots are examined with respect to water balance, other root functions, and intrusion into wastes. Water balance studies have been done at various locations on site, including McGee Ranch, the 300 North grass site, the Artemisia tridentatal Pseudoroegneria spicata community, and at Lower Snively field. Numerous lysimeter studies have examined the role of vegetation in water balance. Work has been reviewed to quantify the relationship plants have on water and wind erosion.

Animal studies have focused on burrowing effects on soil water balance and the transport of buried wastes to the surface. This has been done for small and large mammals on site. Studies done to determine the role of animals on waste transport to the surface are reviewed.

Studies on the role of plants and animals on barriers and climate change at Hanford were reviewed. Climate change studies have focused on assessing the potential range of climate conditions barriers may be exposed to over thousands of years and the potential consequences of such exposure on the plants and animals that may inhabit a barrier, and the water balance of a barrier. Climate change studies indicate that the present interglacial may last another 10,000 years, with the continental glacial ice reaching its maximum extent (important for the Pasco Basin because of its potential for contributing to catastrophic flooding) 100,000 years or more into the future.

The optimal plant community for barrier function is one composed of deep-rooted perennial shrubs and grasses. Deep-rooted perennial shrubs and grasses will minimize the risk of water drainage into the wastes and minimize erosion. The establishment of such a community in the face of the encroachment of invasive alien species is critical for proper barrier function. Investigations into the characteristics of new invasive alien species are needed. Continued research on community dynamics, rooting characteristics, transpiration, and the effects of plants on wind and water erosion is needed to gain confidence in barrier designs. This information needs to be integrated into simulation models of ecological processes to predict the ability of the barrier to function in the future under worst-case scenarios. 
Little research has been done on the effects vegetation may have on infiltration of barrier surfaces. Infiltration depends on soil structure, which is determined by vegetation over time. There is a need to investigate the relationship between vegetation and soil development to properly understand soil physics and infiltration characteristics.

Conclusions drawn from animal studies indicate that animals are not likely to compromise the water relations of the barrier. It should be cautioned, however, that this conclusion is based on short-term studies.

Confidence in the ability of isolation barriers to isolate hazardous wastes from dispersion into the environment will require long-term integrated studies. Such studies will have to develop an understanding of how ecosystems develop over time and how this will influence surface stability and hydrologic properties of barriers. 


\section{Acknowledgments}

Funding was provided by the U.S. Department of Energy's Environmental Restoration Program under contract DE-AC06-76RLO 1830. We thank Dr. W. H. Rickard for his efforts to improve this manuscript and Dr. G. W. Gee for his continued support of this research. 


\section{Contents}

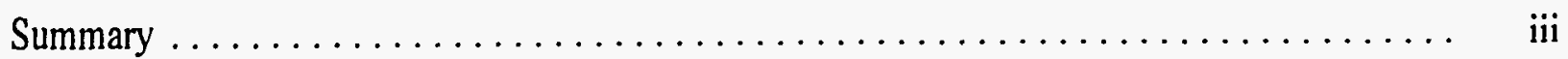



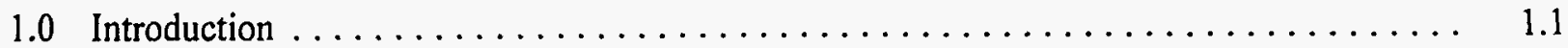

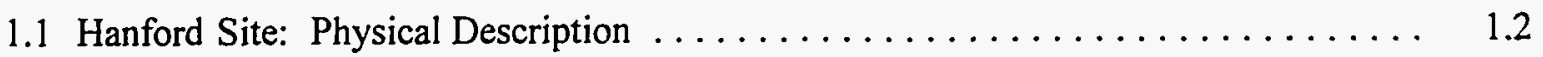

1.2 Plants and Animals Affecting Barrier Design $\ldots \ldots \ldots \ldots \ldots \ldots \ldots \ldots \ldots \ldots \ldots$

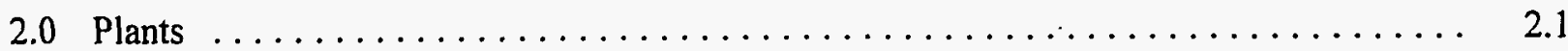

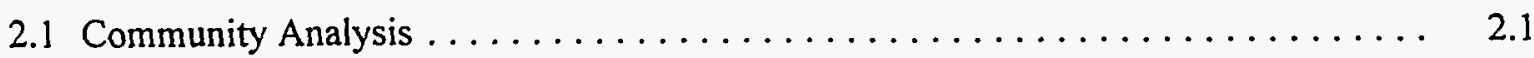

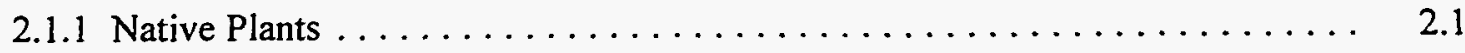

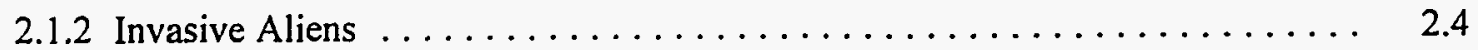

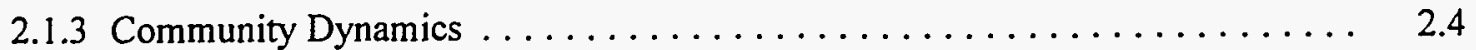

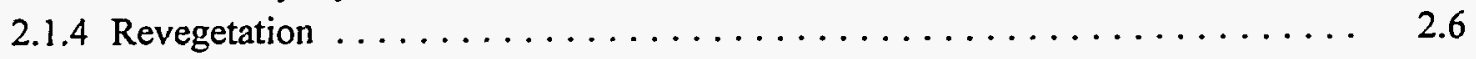



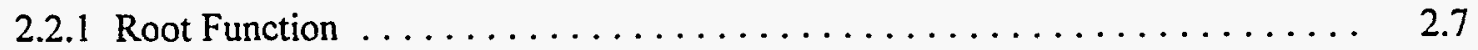

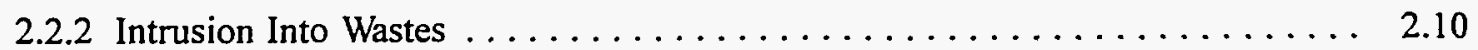

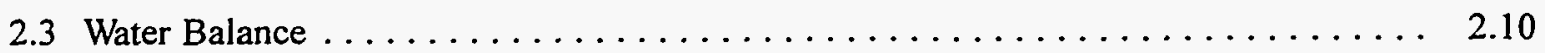

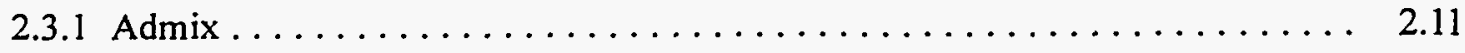

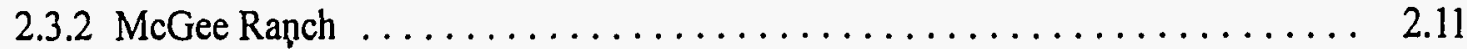



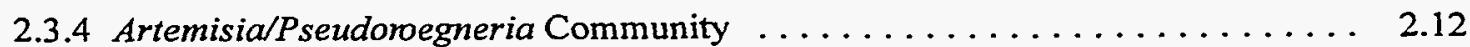

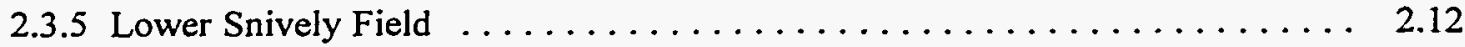

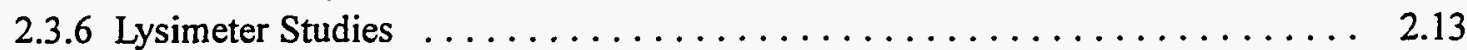



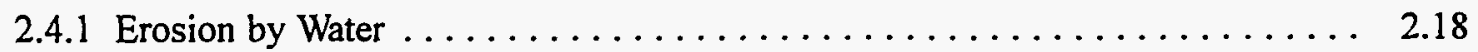

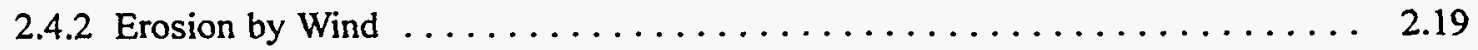

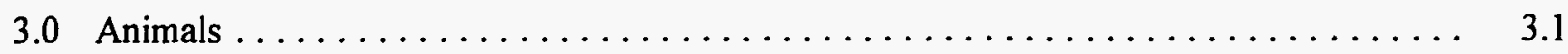



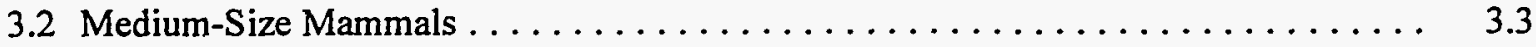

3.3 Soil Moved to the Surface by Mammals $\ldots \ldots \ldots \ldots \ldots \ldots \ldots \ldots \ldots \ldots \ldots$

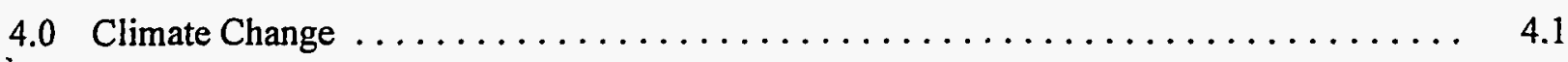

4.1 Effects of Climate Change on Plants and Animals . . . . . . $\ldots \ldots \ldots \ldots \ldots \ldots$



5.0 Conclusions and Recommendations $\ldots \ldots \ldots \ldots \ldots \ldots \ldots \ldots \ldots \ldots \ldots \ldots \ldots \ldots$

6.0 References $\ldots \ldots \ldots \ldots \ldots \ldots \ldots \ldots \ldots \ldots \ldots \ldots \ldots \ldots \ldots \ldots \ldots \ldots \ldots$ 


\section{Figures}

1.1 Permanent Isolation Barrier at Hanford $\ldots \ldots \ldots \ldots \ldots \ldots \ldots \ldots \ldots \ldots \ldots \ldots \ldots$

1.2 The Hanford Site in South-Central Washington State Showing Locations of Study Areas Relevant to the Permanent Isolation Barrier Program . . . . . . . . . 1.3

2.1 Cumulative Storage Change in the Small-Tube Lysimeters $\ldots \ldots \ldots \ldots \ldots \ldots \ldots$

3.1 Mean Seasonal Percent Change in Soil Moisture Around Badger Burrows at the End of Each of the Four Calendar Quarters for $1989 \ldots \ldots \ldots \ldots \ldots \ldots \ldots$

4.1 Normal Monthly Average Precipitation (cm) for Selected Individual Weather Stations in the Western United States for the Period $1931-1960 \ldots \ldots \ldots \ldots \ldots \ldots$

4.2 Major Grassland, Steppe and Shrub Types of Northwestern North America ........

4.3 Predicted Vegetation and Precipitation Changes in Regions Surrounding the Hanford Site Under More Meridional Flow Conditions than at Present . . . . . . . . .

4.4 Predicted Vegetation and Precipitation Changes in Regions Surrounding the Hanford Site Under More Zonal Flow Conditions than at Present .

\section{Tables}

2.1 Native Plant Species of McGee Ranch and the 200 Areas Plateau (n), Invasive Species (i), and Species Used to Revegetate the Prototype Barrier (r) . . . . . . . . .

2.2 Summary of Canopy Cover Provided by Wild Plants at Various Places in the Columbia River Plain Hanford Site and Number of Plant Species in Each Botanical Category .....

2.3 Greatest Observed Rooting Depth of Species at the Hanford Site that Could Live on Barrier Surfaces .

2.4 Results of Analysis of Variance for Storage Change, Evapotranspiration, and Drainage in the Small-Tube Lysimeters 


\subsection{Introduction}

The Pacific Northwest Laboratory (PNL) and other contractors on site (Westinghouse Hanford Company, Kaiser Engineering, Bechtel Hanford Company) have been working together to develop long-term isolation barriers for the near-surface disposal of hazardous wastes on the Hanford Site. The Hanford Site contains $10.3 \%$ of all low-level waste (Fisher 1986) and much of the high-level nuclear waste in the United States. Research on the development of waste isolation barriers at the arid Hanford Site has been ongoing since the mid-1980s (Gee et al. 1993a, Link et al. 1994a). The barriers are being designed to hydrologically isolate the buried wastes for thousands of years (Gee et al. 1992). The prototype barrier design consists of a layer of fine-textured soil overlying multiple layers grading from sand to basalt riprap (Gee et al. 1993a). The capillary break concept has been investigated as a way to minimize water infiltration into buried waste. A capillary break is essentially a layer of fine topsoil over loose rock (Richards 1950). Such a configuration restricts rapid downward movement of water and tends to store water in the upper soil, where it can be readily returned to the atmosphere through evapotranspiration. A capillary break is one of the major design features of the permanent isolation barrier (Figure 1.1) and has been investigated extensively at Hanford (Gee et al. 1993b, Wing and Gee 1993).

All factors that could contribute to waste dispersal should be carefully considered when designing long-term isolation barriers (Waugh et al. 1994a). Wastes can be dispersed by water, wind, plants, and animals. Plants and animals have significant effects on surface layers and can, potentially, compromise a barrier. Thus, it is important-to determine how plants and animals affect the soil water balance, the stability of the surface subjected to wind and water erosion, and the potential for biointrusion into the waste (Wing 1992, Gee et al. 1993a, Link et al. 1994b). Given that the barrier must last for at least 1000 years, it is also important to determine the effects of climate change on the species composition of plant and animal communities (Petersen et al. 1993). Our review of the role of plants and animals on isolation barriers at Hanford includes summaries of studies of plant community dynamics; root intrusion; the influence of plants and animals on wind erosion, water erosion, infiltration, and surface water budgets; and the effects of climate change on plants and animals likely to inhabit the barrier. Figure 1.2 shows the locations of field studies discussed in this review.

This review summarizes knowledge about the plants and animals that might be found on barrier structures at Hanford. It is focused on studies performed for the Hanford Protective Barrier program, but will include information from other Hanford studies. This work is not a comprehensive review of plants and animals on the Hanford Site. A comprehensive review of plants and animals on the FitznerEberhardt Arid Lands Ecology reserve can be found in Rickard et al. (1988), and a comprehensive list of plant species for Hanford in Sackschewsky et al. (1992). 




S9210014.1

Figure 1.1. Permanent Isolation Barrier at Hanford

\subsection{Hanford Site: Physical Description}

The U.S. Department of Energy's (DOE) Hanford Site $\left(46^{\circ} 35^{\prime} \mathrm{N}, 119^{\circ} 44^{\prime} \mathrm{W}\right.$ ) is in south-central Washington state. The Hanford Site is $1480 \mathrm{~km}^{2}$ in area and varies in elevation from 120 to 1200 meters above sea level (m.a.s.l.). The climate is semiarid with hot dry summers and cool wet winters (Stone et al. 1983). The prototype barrier is located on the 200 Area Plateau at 223 m.a.s.l. (see Figure 1.2). Average yearly precipitation at the nearby Hanford Meteorological Station is about $162 \mathrm{~mm}$, falling mostly in the fall and winter. Snowfall ranges from trace amounts to $137 \mathrm{~cm}$, but averages $35 \mathrm{~cm}$. Precipitation increases with elevation in the Rattlesnake Hills. Average yearly precipitation at an elevation of $553 \mathrm{~m}$ is $260 \mathrm{~mm}$. Barriers will all be located at low elevations (approximately $200 \mathrm{~m}$ ) at Hanford.

The soils in the 200 Area Plateau are coarse-textured alluvial sands covered by a mantle of winddeposited fine sands of the Quincy soil series (mixed, mesic Xeric Torripsamments) (Gee et al. 1992). Soils from McGee Ranch, used in the upper layers of the prototype barrier, are silt loams (Hajek 1966, Gee 1987). 




Figure 1.2. The Hanford Site in South-Central Washington State Showing Locations of Study Areas Relevant to the Permanent Isolation Barrier Program 


\subsection{Plants and Animals Affecting Barrier Design}

The natural vegetation of the Hanford Site is representative of the semi-arid shrub-steppe ecoregion of southeastern Washington (Daubenmire 1970). The dominant woody plants are short-stature, widely spaced desert shrubs; Artemisia tridentata (sagebrush) and Purshia tridentata (bitterbrush) are the most common. The herbaceous understory consists mostly of grasses, especially Poa sandbergii (Sandberg's bluegrass) and Bromus tectorum (cheatgrass) (Cline et al. 1977a, Rickard and Sauer 1982, Rickard 1988).

Agricultural settlement of the area that became the Hanford Site began in the mid 1800's. The native plant communities were fragmented by plowing and stressed by overgrazing, accelerating the spread of imported Eurasian weeds. Irrigated fields, abandoned in the early 1940s, have been revegetated with alien annual plants, particularly $B$. tectorum, Sisymbrium altissimum (tumble mustard), Holosteum umbellatum (jagged chickweed), and Salsola kali (Russian thistle). These plants have also invaded places that have never been plowed (Brandt and Rickard 1994) and are now an integral part of the Hanford flora. Since 1940, alien plants have extended their domains, aided by ground-disturbing activities such as road building: pipeline, trench, and well digging; and construction of electrical transmission lines. Burrowing mammals such as Taxidea taxos (badger), Spermophilus townsendii (ground squirrel), Thomomys talpoides (pocket gopher), and Perognathus parvus (pocket mouse) are relevant to this study because they can dig into the barriers. 


\subsection{Plants}

Plants have significant effects on upper layers and can potentially compromise a barrier (Link et al. 1994a). Thus, it is important to determine how plants affect water infiltration, soil water storage, and evapotranspiration. Plants help stabilize surface soils from wind and water erosion; however, deeply rooted plants can also intrude into buried wastes (Wing 1992, Gee et al. 1993a). These issues will be addressed in the context of research conducted on plant community structure, root intrusion, water balance, water erosion, wind erosion, and revegetation.

\subsection{Community Analysis}

Community analysis includes species composition, examination of relative abundance of vascular - plants at Hanford, and revegetation efforts that are relevant to barrier concerns. Table 2.1 lists selected dryland vascular plant species found at McGee Ranch and the 200 Areas Plateau, including those that could invade the area and species used to revegetate the prototype barrier [after Price and Rickard (1973), Sackschewsky et al. (1992), Waugh et al. (1994a) and Link et al. (1994b)]. The species listed are identified with scientific and common names. Table 2.2 summarizes the canopy cover on the Columbia River plain.

\subsubsection{Native Plants}

The Hanford Site resides within the sagebrush-bunchgrass $A$. tridentata/Agropyron spicatum [Pseudoregneria spicata] vegetation zone as described by Daubenmire (1970). The plant communities present in the parts of the Hanford Site in which most of the permanent isolation barriers will be constructed have been further delineated as $A$. tridentata/P. sandbergii/B. tectorum and $A$. tridentata/ $P$. tridentata/P. sandbergii community types (Cline et al. 1975). The common native species of McGee Ranch include the shrubs (Grayia spinosa, A. tridentata, and Chrysothamnus nauseosus), several species of forbs (Machaeranthera canescens, Sphaeralcea munroana, Astragalus carcinus, and Helianthus cusickii), and the perennial grasses (P. sandbergii, Sitanion hystrix, and Oryzopsis hymenoides).

Other native species found in the 200 Area Plateau that potentially could grow on barrier surfaces include the shrubs (Chrysothamnus viscidiflorus, $P$. tridentata) and perennial bunchgrasses (Stipa comata, $S$. hystrix, $O$. hymenoides, Sporobolus cryptandrus, and Koeleria cristata.). Common native annual species include Ambrosia acanthicarpa and Descurainia pinnata. The characteristic perennial and annual forbs that occur in both the native communities and in disturbed areas are described in Price and Rickard (1973) and in Sackschewsky et al. (1992). 
Table 2.1. Native Plant Species of McGee Ranch and the 200 Areas Plateau (n), Invasive Species (i), and Species Used to Revegetate the Prototype Barrier (r)

\begin{tabular}{|c|c|c|}
\hline Scientific Name & Common Names & Notes \\
\hline Abronia mellifera & White sand verbena & $\mathrm{n}$ \\
\hline Achillaea millifolium & Yarrow & $\mathrm{n}$ \\
\hline Agropyron dasytachyum & Thickspike wheatgrass & $\mathrm{n}, \mathrm{r}$ \\
\hline Ambrosia acanthicarpa & Bur ragweed & $\bar{n}$ \\
\hline Amsinckia tessellata & Tessellate fiddleneck & $\mathrm{n}$ \\
\hline Astragalus carcinus & Buckwheat milkvetch & $\mathrm{n}$ \\
\hline Astragalus purshii & Woolley-pod milkvetch & $\mathrm{n}$ \\
\hline Artemisia tridentata & Big sagebrush & $n, r$ \\
\hline Balsamorhiza careyana & Carey's balsamroot & $\mathrm{n}$ \\
\hline Brodiaea douglasii & Brodiaea & $\mathrm{n}$ \\
\hline Bromus tectorum & Cheatgrass & $\overline{\mathrm{i}}$ \\
\hline Centaurea diffusa & Diffuse knapweed & $\bar{i}$ \\
\hline Centaurea maculosa & Spotted knapweed & $\overline{\mathrm{i}}$ \\
\hline Centaurea solstitialis & Yellow starthistle & $\overline{\mathrm{i}}$ \\
\hline Chenopodium leptophyllum & Slimleaf goosefoot & $\mathrm{n}$ \\
\hline Chaenactis douglasii & Hoary false-yarrow & $\mathrm{n}$ \\
\hline Chrysothamnus nauseosus & Gray rabbitbrush & $\mathrm{n}, \mathrm{r}$ \\
\hline Chrysothamnus viscidiflorus & Green rabbitbrush & $\bar{n}$ \\
\hline Comandra pallida & Pale bastard toadflax & $\mathbf{n}$ \\
\hline Conyza canadensis & Horseweed & $\bar{n}$ \\
\hline Crepis atrabarba & Slender hawksbeard & $\mathrm{n}$ \\
\hline Cryptantha circumscissa & Matted cryptantha & $\mathrm{n}$ \\
\hline Cryptantha pterocarya & Winged cryptantha & $\mathrm{n}$. \\
\hline Cymopteris terebinthinus & Turpentine cymopteris & $\mathrm{n}$ \\
\hline Delphinium nuttallianum & Upland larkspur & $\overline{\mathbf{n}}$ \\
\hline Descurainia pinnata & Western tansymustard & $\mathrm{n}$ \\
\hline Erigeron filifolius & Threadleaf fleabane & $\mathrm{n}$ \\
\hline Erigeron pumilus & Shaggy fleabane & $\mathrm{n}$ \\
\hline Erodium cicutarium & Filaree & i \\
\hline Erysimum asperum & Rough wallflower & $\mathrm{n}$ \\
\hline Gilia leptomeria & Great Basin gilia & $\mathrm{n}$ \\
\hline Grayia spinosa & Spiny hopsage & $\overline{\mathrm{n}}$ \\
\hline
\end{tabular}


Table 2.1. (contd)

\begin{tabular}{|c|c|c|}
\hline Scientific Name & Common Names & Notes \\
\hline Helianthus cusickii & Cusick's sunflower & $\mathrm{n}$ \\
\hline Koeleria cristata & Prairie junegrass & $\bar{n}$ \\
\hline Lactuca serriola & Prickly lettuce & $\overline{\mathrm{i}}$ \\
\hline Lappula redowskii & Western stickseed & $\mathrm{n}$ \\
\hline Layia glandulosa & White-daisy tidytips & $\mathrm{n}$ \\
\hline Lepidium perfoliatum & Clasping pepperweed & $\overline{\mathrm{i}}$ \\
\hline Leptodactylon pungens & Prickly phlox & $\bar{n}$ \\
\hline Lomatium grayi & Desert parsley & $\mathrm{n}$ \\
\hline Machaeranthera canescens & Hoary aster & $\mathrm{n}$ \\
\hline Melilotus alba & White sweetclover & $\overline{\mathrm{i}}$ \\
\hline Melilotus officinalis & Yellow sweetclover & $\overline{\mathrm{i}}$ \\
\hline Microsteris gracilis & Pink microsteris & $\mathrm{n}$ \\
\hline Oenothera pallida & Pale evening primrose & $\mathrm{n}$ \\
\hline Oryzopsis hymenoides & Indian ricegrass & $\mathrm{n}, \mathrm{r}$ \\
\hline Penstemon acuminatus & Sand beardtongue & $\bar{n}$ \\
\hline Phacelia linearis & Threadleaf scorpionweed & $\bar{n}$ \\
\hline Phlox longifolia & Longleaf phlox & $\bar{n}$ \\
\hline Poa ampla & Sherman big bluegrass & $r$ \\
\hline Poa sandbergii & Sandberg's bluegrass & $\mathrm{n}, \mathrm{r}$ \\
\hline Pseudoroegneria spicata & Blue-bunch wheatgrass & $\mathrm{r}$ \\
\hline Psoralea lanceolata & Scurf pea & $\mathrm{n}$ \\
\hline Purshia tridentata & Bitterbrush & $\mathbf{n}$ \\
\hline Salsola kali & Russian thistle & $\overline{\mathrm{i}}$ \\
\hline Salvia dorrii & Gray-ball sage & n \\
\hline Sisymbrium altissimum & Tumblemustard & $\overline{\mathrm{i}}$ \\
\hline Sitanion hystrix & Squirreltail grass & $n, r$ \\
\hline Sphaeralcea munroana & Munro's globe-mallow & $n$ \\
\hline Sporoblus cryptandrus & Sand dropseed & $\mathrm{n}$ \\
\hline Stipa comata & Needle-and-thread grass & $\mathrm{n}, \mathrm{r}$ \\
\hline Thelypodium laciniatum & Cutleaf ladysfoot mustard & $\mathrm{n}$ \\
\hline Townsendia florifer & Daisy & $\bar{n}$ \\
\hline Tragopogon dubius & Yellow salsify & $\overline{\mathrm{i}}$ \\
\hline
\end{tabular}


Table 2.2. Summary of Canopy Cover Provided by Wild Plants at Various Places in the Columbia River Plain Hanford Site and Number of Plant Species in Each Botanical Category

\begin{tabular}{|c|c|c|c|c|c|c|}
\hline \multirow[t]{2}{*}{ Botanical Category } & \multicolumn{2}{|c|}{$\begin{array}{c}\text { Cold Creek, } 200 \\
\text { Area }^{(a)}\end{array}$} & \multicolumn{2}{|c|}{$\begin{array}{l}\text { B-C Cribs, } \\
200 \text { Area }^{(b)}\end{array}$} & \multicolumn{2}{|c|}{$\begin{array}{c}\text { Supply System, } \\
300 \text { Area }^{(c)}\end{array}$} \\
\hline & \%cover & \#species & \% cover & \#species & \%cover & \#species \\
\hline Desert Shrubs & 20 & 5 & 18 & 2 & 26 & 4 \\
\hline Bunchgrass & 13 & 5 & 2 & 1 & 10 & 2 \\
\hline Perennial Forbs & $<1$ & 10 & 1 & 8 & 4 & 9 \\
\hline Annual Grass ${ }^{(d)}$ & 12 & 2 & 19 & 2 & 56 & 2 \\
\hline Annual Forb ${ }^{\text {(d) }}$ & $<1$ & 14 & 14 & $\overline{9}$ & 28 & 16 \\
\hline Total & 46 & 36 & 54 & 22 & $124^{(c)}$ & 33 \\
\hline \multicolumn{7}{|c|}{$\begin{array}{l}\text { (a) Data from Rickard and Schuler } 1988 . \\
\text { (b) Data from Cline et al. } 1977 \mathrm{a} \text {. } \\
\text { (c) Washington Public Power Supply System. Data from Rickard and Sauer } 1982 . \\
\text { (d) Annual grass and annual forb canopy varies greatly from year to year depending } \\
\text { upon rainfall. } \\
\text { (e) Exceeds } 100 \% \text { cover because of overlapping layers of canopy. }\end{array}$} \\
\hline
\end{tabular}

\subsubsection{Invasive Aliens}

In the 1800 s, settlers introduced a number of invasive alien plant species to the Columbia Basin. These species, mostly annuals, are now important components of the Hanford Site flora (Sackschewsky et al. 1992, Brandt and Rickard 1994). Most notable of these are B. tectorum, S. kali, and S. altissimum. However, a number of other species are very common, including Lactuca serriola and Tragopogon dubius. Knapweed species have become established on the Hanford Site, including C. solstitialis, Centaurea repens, Centaurea diffusa, and Centaurea maculosa, of which $C$. diffusa is most common (Roché and Roché 1988). The range and the population sizes of these species appear to be expanding in the Columbia Basin, and they may spread to barrier surfaces in the future.

\subsubsection{Community Dynamics}

Plant community dynamics describe the changes that occur within a plant community over time. These changes may include alterations of the mixture of plant species within the community, changes in the abundance and density of individual species, and the introduction and extinction of species. These changes can occur over both short-term and long-term time scales. Short-term changes in species composition are related to disturbance and the introduction of alien species. Long-term changes in plant communities usually occur in response to climatic changes. Climatically induced changes in the plant community could significantly alter long-term barrier performance, especially if the new conditions and 
resulting plant community do not match the design criteria of the protective barrier (Sackschewsky et al. 1991). For example, if the climate becomes significantly wetter, deep-rooted plants such as trees could become established on the barrier surface. The roots of these plants may significantly stress the capillary break structure of the protective barrier, and could eventually intrude into the buried waste. Conversely, these plants would greatly increase the amount of water extracted from the soil through transpiration (Link et al. 1994a).

The vegetation on engineered covers will change over time. Understanding the bounds for these changes is important in designing protective barriers that are expected to function for hundreds to thousands of years. The plant community is expected to go through many successional cycles during the lifetime of the barrier. The first cycle will occur at the time of initial barrier construction and revegetation. Numerous additional cycles will occur in response to both human-induced and natural disturbances, such as fire. The plant community will also shift over time in response to changes in climatic conditions, such as changes in temperature and precipitation. Climate change and disturbances can alter the numbers, types, and diversity of species, and may be accompanied by changes in water extraction rates. Even under the present climate, and without disturbance, there is significant seasonal and year-to-year variation in factors such as species abundance, biomass production, and transpiration rates in response to variation in precipitation and temperature (Waugh et al. 1994b).

Without revegetation efforts to create a perennial plant community on new barrier surfaces, plant community dynamics will likely follow a chronosequence described in Waugh and Link (1988) for disturbed areas. Their analysis was based on observations contained in Rogers and Rickard (1977). The initial dominant plant found on disturbed burial sites is $S$. kali, which becomes less abundant as $B$. tectorum becomes dominant. Other species that established themselves include $P$. sandbergii, $S$. altissimum, and $C$. nauseosus. The oldest disturbed surfaces were dominated by $B$. tectorum and $C$. nauseosus. The current prototype barrier was planted with perennials and is not expected to go through a disturbance sequence. The alien grass $B$. tectorum is an important component of local plant communities. Although this species is usually associated with disturbed areas (i.e., Harris 1967, Daubenmire 1975), it is also becoming established within areas that have not been highly disturbed in the past (Brandt and Rickard 1994). Bromus tectorum establishes itself in areas that have been disturbed mechanically, by fire, or by heavy grazing, primarily because it extracts water from the soil faster and earlier than native species (Harris 1967, Harris and Wilson 1970, Daubenmire 1975, Melgoza et al. 1990). Bromus tectorum was first documented in the State of Washington in 1893, and has since rapidly spread throughout the Columbia Basin and most of the western United States (Klemmedson and Smith 1964).

Prior to European settlement of the Columbia Basin, fire was the only major disturbance to which local plant communities were exposed. The native population did not engage in agricultural activities, there were no large, congregating ungulates to cause intensive grazing pressure (Mack and Thompson 1982), and there were few annual species capable of dominating disturbed communities. Therefore, the original successional pattern following fire would have consisted of a temporary loss of A. tridentata. Artemisia tridentata is susceptible to fire because it cannot resprout after burning (Daubenmire 1975). Native bunchgrasses resprout after fire, and low intensity burning is a temporary 
setback to these species (Franklin and Dyrness 1973). The native bunchgrasses are highly susceptible to grazing (Mack and Thompson 1982), whereas A. tridentata is not (Franklin and Dyrness 1973). Therefore, a combination of fire and grazing removes both native dominant components from the community, and allows $B$. tectorum to invade and become established. The litter production of $B$. tectorum communities tends to be several times higher than that of native stands (Rickard et al. 1977), resulting in an increase in the incidence and intensity of fires. Once established, $B$. tectorum may never relinquish its position, thus arresting the normal successional pattern at what would be considered an early stage in most plant communities (Rickard and Sauer 1982). The only native species that have been noted to become established in $B$. tectorum fields after 50 years are C. nauseosus and S. cryptandrus (Daubenmire 1975, Brandt and Rickard 1994).

\subsubsection{Revegetation}

At the Hanford Site, early revegetation efforts focused on stabilizing the surface against erosion and discouraging roots from entering buried wastes. Cline and Uresk (1979) established shallowrooted annuals ( $B$. tectorum) instead of deep-rooted perennials to stabilize soil surfaces and preclude the intrusion of $S$. kali roots into buried radioactive wastes. This required nitrogen fertilization and irrigation in the fall, and soil stabilization with straw to prevent wind erosion.

At McGee Ranch, Waugh et al. (1994c) documented community dynamics after revegetation over 5 years on disturbed soils receiving differing amounts of gravel admix and water. Native perennial shrubs and grasses were seeded into the area. These included Agropyron sibericum, Agropyron dasystachyum, $O$. hymenoides, Poa canbyi, Festuca ovina, $C$. nauseosus var. albicaulis, $P$. tridentata, $A$. tridentata, and $G$. spinosa. The perennials that survived were the grasses, $A$. sibericum and $A$. dasystachyum (only in irrigated plots) and the shrub, $A$. tridentata. Bromus tectorum and $S$. kali invaded the study area from adjacent areas. The percent cover of $B$. tectorum increased over the observation period and the cover of $S$. kali first increased then decreased to less than $5 \%$ cover. In the ambient precipitation plots, after 5 years $B$. tectorum was dominant with minor cover by $S$. kali and A. tridentata. This is a common result on disturbed grounds at Hanford.

Other revegetation efforts at Hanford have successfully re-established deep-rooted perennial shrubs (A. tridentata and G. spinosa) on the disturbed Basalt Waste Isolation Project (BWIP) areas (Brandt et al. 1990, Brandt and Rickard 1990). These species were successfully established as seedlings. Recent efforts by Brandt et al. (1992) demonstrated successful revegetation with grasses in BWIP areas. They prepared seedbeds in the fall, testing various combinations of McGee Ranch soils, fertilizer, compost and wood chips. They seeded $P$. sandbergii, S. hystrix, $S$. comata, and Melilotus alba. The highest density of $P$. sandbergii occurred where seedbed treatments consisted of a control (no treatments) and only fertilizer disked into the soil. They also recorded the presence of $S$. kali and B. tectorum in the study plots. 


\section{Prototype Vegetation Establishment}

The prototype barrier surface and surrounding disturbed areas were revegetated in the fall of 1994 . Revegetation work was done separately to establish perennial shrubs and to establish perennial grasses.

Revegetation with perennial shrubs was done by collecting shrub seeds, growing seedlings, and then transplanting the seedlings on the surface of the prototype barrier. Seeds of $A$. tridentata and $C$. nauseosus were collected from McGee Ranch on December 23, 1993. The entire inflorescence of $A$. tridentata and the fruits of $C$. nauseosus were harvested and stored in plastic bags in the field. The material was transported to the Arid Lands Ecology (ALE) laboratory facility, taken out of the plastic bags, and placed on table tops to dry. It was stored in the dark and at room temperature until shipped to a nursery. The seed was cleaned by April 12 for germination. All the seed was sown on May 4, 1994. Germination was complete by about June 10 , with germination success of $40 \%$ for $C$. nauseosus and $60 \%$ for $A$. tridentata. Seedlings were grown in $164 \mathrm{~cm}^{3}$ tubes (Gee et al. 1994). On November 7 , planting was initiated. Twenty-seven hundred holes were drilled at a density of one hole $\mathrm{m}^{-2}$ on the prototype surface. Two seedlings were placed in each hole. There were $1350 \mathrm{C}$. nauseosus and $4050 \mathrm{~A}$. tridentata seedlings planted. The seedlings were approximately $20 \mathrm{~cm}$ tall.

Perennial grasses were established by hydroseeding the barrier surface and surrounding slopes. The hydroseeding mix included seeds, fertilizer, mulch and a tacking agent. The native perennial grass seed mixture included $P$. sandbergii, $A$. dasystachyum, $O$. hymenoides, Poa ampla, $S$. comata, $P$. spicata, and $S$. hystrix. The fertilizer was applied as $67 \mathrm{~kg} \mathrm{ha}^{-12}\left(60 \mathrm{lb} \mathrm{acre}^{-1}\right)$ of total nitrogen, $67 \mathrm{~kg} \mathrm{ha}^{-1}$ of available phosphoric acid $\left(\mathrm{P}_{2} \mathrm{O}_{5}\right)$, and $67 \mathrm{~kg} \mathrm{ha}^{-1}$ of soluble potash $\left(\mathrm{K}_{2} \mathrm{O}\right)$ in solution. The mulch was applied as $2240 \mathrm{~kg} \mathrm{ha}^{-1}$ of Eco-Fibre $100 \%$ virgin wood fiber. A degradable glue was added to the mulch as a tacking agent at $67 \mathrm{~kg} \mathrm{ha}^{-1}$. The hydroseeding was applied on November 10 with the above material in a slurry form. The material was mixed with water using power augers in a large tank on a truck, then dispersed under pressure from large hoses onto the ground.

\subsection{Roots}

For the prototype barrier design, in which fine soils overlie graded layers, the optimal root distribution is one in which roots fully exploit the fine-soil layer for maximum water extraction. However, growth of deep-rooted plants on the barrier presents the possibility of root intrusion into the wastes and subsequent biotic transport of hazardous materials to the barrier surface. Knowledge of root depth, growth, biomass, root length density, vertical and horizontal dispersion patterns, root/soil interactions, and water uptake patterns is needed to model and predict the removal of soil water through transpiration and the role of roots in the uptake of wastes (Link et al. 1993).

\subsubsection{Root Function}

Rooting depth and dispersion are controlling factors determining soil water dynamics. Accumulation of water deep in the upper profile of the prototype barrier will depend on the depth of the rooting zone. Table 2.3 summarizes rooting depth observations from eight studies at Hanford. Rooting depth 
Table 2.3. Greatest Observed Rooting Depth of Species at the Hanford Site that Could Live on Barrier Surfaces

\begin{tabular}{|c|c|c|c|c|}
\hline Site & Species & Soil Type & $\begin{array}{l}\text { Root } \\
\text { Depth } \\
\text { (cm) }\end{array}$ & Reference \\
\hline $\begin{array}{l}\text { Pit } 29 \\
\text { Trench }\end{array}$ & Artemisia tridentata & sandy-loam to sand & 230 & Waugh et al. (1994a) \\
\hline $\begin{array}{l}\text { PUREX } \\
\text { Trench }\end{array}$ & $\begin{array}{l}\text { A. tridentata } \\
\text { Purshia tridentata }\end{array}$ & sandy-loam to sand & $\begin{array}{l}170 \\
260\end{array}$ & Waugh et al. (1994a) \\
\hline $\begin{array}{l}\text { PUREX } \\
\text { Pit Face }\end{array}$ & $\begin{array}{l}\text { Ambrosia acanthicarpa } \\
\text { Salsola kali } \\
\text { Sisymbrium altissimum }\end{array}$ & sandy-loam to sand & $\begin{array}{r}132 \\
137 \\
97\end{array}$ & $\begin{array}{l}\text { Waugh et al. (1994a) } \\
\text { Waugh et al. (1994a) } \\
\text { Waugh et al. (1994a) }\end{array}$ \\
\hline $\begin{array}{l}\text { Lower } \\
\text { Snively }\end{array}$ & Bromus tectorum & silt-loam & 80 & Cline et al. (1977b) \\
\hline $\begin{array}{l}\text { Lower } \\
\text { Snively }\end{array}$ & Bromus tectorum & silt-loam & 60 & Downs et al. (1993) \\
\hline $\begin{array}{l}\text { McGee } \\
\text { Ranch }\end{array}$ & $\begin{array}{l}\text { A. tridentata } \\
\text { Grayia spinosa }\end{array}$ & silt-loam & $\begin{array}{l}200 \\
200\end{array}$ & Link et al. (1994c) \\
\hline $\begin{array}{l}300 \mathrm{~N} \\
\text { Grass }\end{array}$ & $\begin{array}{l}\text { B. tectorum } \\
\text { Poa sandbergii }\end{array}$ & loamy-sand to sand & $\begin{array}{l}50 \\
35\end{array}$ & $\begin{array}{l}\text { Link et al. (1990a) } \\
\text { Link et al. (1990a) }\end{array}$ \\
\hline 200 Area & Chrysothamnus nauseosus & sandy-loam to sand & 240 & Klepper et al. (1978) \\
\hline FLTF & A. tridentata & silt to rock with depth & 300 & Campbell (1991) \\
\hline 200 Area & $\begin{array}{l}\text { C. nauseosus } \\
\text { A. tridentata } \\
\text { S. kali } \\
\text { A. acanthicarpa } \\
\text { P. tridentata } \\
\text { Aster canescens } \\
\text { Stipa comata } \\
\text { Oryzopsis hymenoides } \\
\text { Cymopteris terebinthinus } \\
\text { G. spinosa } \\
\text { Eriogonum niveum } \\
\text { Chrysothamnus } \\
\text { viscidiflorus } \\
\text { Lactuca serriola } \\
\text { Balsamorhiza careyana }\end{array}$ & $\begin{array}{l}\text { sandy-loam to sand } \\
\text { sandy-loam to sand } \\
\text { sandy-loam to sand } \\
\text { sandy-loam to sand } \\
\text { sandy-loam to sand } \\
\text { sandy-loam to sand } \\
\text { sandy-loam to sand } \\
\text { sandy-loam to sand } \\
\text { sandy-loam to sand } \\
\text { sandy-loam to sand } \\
\text { sandy-loam to sand } \\
\text { sandy-loam to sand } \\
\text { sandy-loam to sand } \\
\text { sandy-loam to sand }\end{array}$ & $\begin{array}{r}183 \\
200 \\
172 \\
162 \\
300 \\
155 \\
160 \\
125 \\
145 \\
195 \\
150 \\
160 \\
\\
\\
85 \\
150\end{array}$ & $\begin{array}{l}\text { Klepper et al. (1985) } \\
\text { Klepper et al. (1985) } \\
\text { Klepper et al. (1985) } \\
\text { Klepper et al. (1985) } \\
\text { Klepper et al. (1985) } \\
\text { Klepper et al. (1985) } \\
\text { Klepper et al. (1985) } \\
\text { Klepper et al. (1985) } \\
\text { Klepper et al. (1985) } \\
\text { Klepper et al. (1985) } \\
\text { Klepper et al. (1985) } \\
\text { Klepper et al. (1985) } \\
\text { Klepper et al. (1985) } \\
\text { Klepper et al. (1985) }\end{array}$ \\
\hline
\end{tabular}


is highly dependent on the species, ranging from $35 \mathrm{~cm}$ for $P$. sandbergii to $300 \mathrm{~cm}$ for $P$. tridentata. Roots of $A$. tridentata have been observed at a depth of $230 \mathrm{~cm}$ in a sandy-loam to sandy soil (Waugh et al. 1994a), and $300 \mathrm{~cm}$ in completely wetted barrier soil (Campbell and Gee 1990, Campbell 1991). Roots of $C$. nauseosus have been observed at a depth of $240 \mathrm{~cm}$ (Klepper et al. 1978). Bromus tectorum rooting depth has been observed down to $80 \mathrm{~cm}$ in silt-loam soils (Cline et al. 1977b) and $50 \mathrm{~cm}$ in sandy soils (Link et al. 1990a). More water will accumulate deep in the profile if shallowrooted plants, such as $B$. tectorum, dominate the surface than if deep-rooted plants dominate (Cline et al. 1977b, Link et al. 1990b, Gee et al. 1992).

Root dispersion under annual and perennial grasses and the shrub $A$. tridentata was assessed at McGee Ranch by Downs et al. (1991b). During this study, roots were observed along a trench wall down to a depth of $1 \mathrm{~m}$. Roots were counted in $5-\mathrm{cm}$ depth increments in a $1-\mathrm{m}^{2}$ area. Under areas covered by both grass and $A$. tridentata, grass roots were more common above the $20 \mathrm{~cm}$ depth and A. tridentata roots were more common below that depth.

Root biomass has been examined in several field sites at Hanford. In the Artemisial Pseudoroegneria communities on ALE, root biomass ranged from $286 \mathrm{~g} \mathrm{~m}^{-2}$ at the $0-1 \mathrm{dm}$ depth to $76 \mathrm{~g} \mathrm{~m}^{-2}$ at the 7-8 dm depth at the end of the growing season (Rickard and Vaughan 1988). Significant seasonal and year-to-year variation in root biomass was also observed. In a $B$. tectorum community (Lower Snively field), Rickard and Vaughan (1988) observed a maximum root biomass of a little over $500 \mathrm{~g} \mathrm{~m}^{-2}$ at the $0-1 \mathrm{dm}$ depth with decreasing amounts down to 7-8 dm depth. About $69 \%$ of the root biomass was located near the surface. In an $A$. tridentata community between the 200 East and 200 West Areas, Cline et al. (1977a) observed a total root mass down to $1 \mathrm{~m}$ of $368 \mathrm{~g} \mathrm{~m}^{-1}$ with $55 \%$ of the biomass above the $30 \mathrm{~cm}$ depth.

Root density (biomass/volume of soil) data has been collected more recently (Klepper et al. 1985, Downs et al. 1993, Link et al. 1994c). Klepper et al. (1985) report root density values ranging from $0.14 \mathrm{~g} \mathrm{dm}^{-3}$ at the $50 \mathrm{~cm}$ depth to $0.003 \mathrm{~g} \mathrm{dm}^{-3}$ at the $200 \mathrm{~cm}$ depth under $A$. tridentata; $0.04 \mathrm{~g} \mathrm{dm}^{-3}$ at the $50 \mathrm{~cm}$ depth to $0.005 \mathrm{~g} \mathrm{dm}^{-3}$ at the $200 \mathrm{~cm}$ depth under $C$. nauseosus; $0.17 \mathrm{~g} \mathrm{dm}^{-3}$ at the $50 \mathrm{~cm}$ depth to $0.001 \mathrm{~g} \mathrm{dm}^{-3}$ at the $200 \mathrm{~cm}$ depth under $S$. kali; and $0.03 \mathrm{~g} \mathrm{dm}^{-3}$ at the $50 \mathrm{~cm}$ depth to $0.009 \mathrm{~g} \mathrm{dm}^{-3}$ at the $150 \mathrm{~cm}$ depth under $A$. acanthicarpa. Root density values of $B$. tectorum at Lower Snively field ranged from about $3.4 \mathrm{~g} \mathrm{dm}^{-3}$ at the $10 \mathrm{~cm}$ depth to $0.2 \mathrm{~g} \mathrm{dm}^{-3}$ at the $60 \mathrm{~cm}$ depth in May, 1990. These values are nearly twice those obtained in March (Downs et al. 1993). At McGee Ranch, root density was measured beneath $G$. spinosa, $A$. tridentata, and under annual and perennial grasses (Link et al. 1994c). Observations were taken down to a depth of $220 \mathrm{~cm}$. The rooting density beneath $G$. spinosa was an order of magnitude greater than in the other two conditions. The root density under G. spinosa near the surface was $19 \mathrm{~g} \mathrm{dm}^{-3}$ and $0.014 \mathrm{~g} \mathrm{dm}^{-3}$ at a depth of $220 \mathrm{~cm}$. The root density under $A$. tridentata near the surface was $0.9 \mathrm{~g} \mathrm{dm}^{-3}$ and $0.1 \mathrm{~g} \mathrm{dm}^{-3}$ at a depth of $195 \mathrm{~cm}$. The root density under annual and perennial grasses near the surface was $0.6 \mathrm{~g} \mathrm{dm}^{-3}$ and $0.2 \mathrm{~g} \mathrm{dm}^{-3}$ at a depth of $195 \mathrm{~cm}$. At McGee Ranch these species coexist, and it is possible that roots at depth under the annual and perennial grasses have components of the shrubs (Link et al. 1994c). 


\subsubsection{Intrusion Into Wastes}

Over time, plants will establish on barrier surfaces, leading to the potential for roots to intrude into wastes. Root intrusion depends on the ability of roots to penetrate barrier materials (Suter II et al. 1993). Roots may transport wastes to the shoots (Hakonson et al. 1992). Decomposing roots can leave channels for the movement of water and vapors into buried wastes (Nyhan 1989).

Root intrusion into buried wastes has been studied at Hanford for many years. Deèp-rooted plants [C. nauseosus (Klepper et al. 1978), S. kali (Selders 1950)] were shown to accumulate fission products as a consequence of roots penetrating wastes. Uptake of radionuclides at Hanford was further demonstrated in pot experiments with B. tectorum and S. kali (Price 1973; Routson 1975). In the past, attempts were made to prevent intrusion of roots into buried wastes by maintaining a loose rock layer between the waste and the surface soils (Cline et al. 1980). Cline et al. (1980) observed roots of $S$. kali penetrating through a gravel layer where topsoil had filtered through the rocks and the rocks were wet. The ability of roots to grow on the surfaces of wet rocks was documented by Campbell (1991), who observed $A$. tridentata roots penetrating to a depth of $3 \mathrm{~m}$ in clear lysimeters. Cline et al. (1980) found that when small stones were placed on top of the loose rock layer, fewer roots of $S$. kali passed through to the loose rock layer. They concluded that root growth rates were reduced by air in spaces amongst the rocks. Cline et al. (1980) also found that a design with asphalt on small rocks on top of the larger stones prevented all roots from penetrating the loose rock layer.

Caldwell (1992) suggests, from an engineering perspective, that roots can be kept out of waste zones by a filter between the rooted upper soil zone and a lower coarse rock layer or biointrusion layer. Roots will not grow in coarse rock where there is no water or soil. Others have prevented roots from entering wastes by keeping the surface barren of plants. This has been done by placing gravel on the surface and maintaining an herbicide program. This practice, unfortunately, leads to deep water infiltration (Gee et al. 1992, Burt and Cox 1993).

On the Hanford prototype barrier, the chances that roots will. enter buried wastes are small because there will be a deep loose rock layer between the waste and the surface soils. As long as this zone is dry, roots are not likely to enter. Even if this zone should become wet, the asphalt layer below it should prevent roots from entering the waste below the asphalt.

\subsection{Water Balance}

The water balance of soils depends on plant species, plant density, size of area, transpiration, community structure, precipitation, climate, and soil type. Most studies have been done to determine the surface water balance and recharge characteristics at Hanford. These studies encompass a wide variety of plant species, communities, plant density, size of area, precipitation, climate, and soil type. The water balance studies have been done in the field in undisturbed and disturbed areas using gravimetric, neutron probe, lysimetry, and gas exchange techniques. 
It has been established that areas dominated by shallow-rooted annuals such as $B$. tectorum can allow water to pass beneath the root zone which can, potentially, lead to groundwater recharge (Cline et al. 1977b). At the $45 \mathrm{~cm}$ depth in early July 1987, there was about $8 \%$ volumetric soil water content in an $A$. tridentata/P. spicata stand. This is significantly less than the $15 \%$ volumetric soil water content found in the $B$. tectorum field (Link et al. 1988). Variation in the rooting depth of deep-rooted perennials is associated with variation in soil water storage (Link et al. 1990b).

\subsubsection{Admix}

At McGee Ranch, a study was done to determine the effect of gravel admixtures on soil water dynamics (Waugh et al. 1994c). The major hypothesis tested was that, even with higher-than-normal rainfall, vegetation will efficiently extract water from soils covered with small-gravel admixtures. Vegetation seasonally depleted root-zone water storage to about $6.5 \%$ volume, regardless of the amount of precipitation or the presence of gravel admixture amiendments. In contrast, soil water storage over a 5 -year period increased to a depth of $225 \mathrm{~cm}$ on plots without plants.

\subsubsection{McGee Ranch}

Two studies have been done at McGee Ranch to document water balance (Link et al. 1994c) and to gain a better understanding of how the major shrubs transpire water (Link et al. 1995a). The relationships of soil water dynamics to arid land coppice dune/swale topography and associated plants were examined under normal and enhanced precipitation (Link et al. 1994c). Three conditions were compared: coppice dunes dominated by $G$. spinosa; sparsely vegetated swales; and swales dominated by $A$. tridentata. Sparsely vegetated swales were wetter than $G$. spinosa coppice dunes or $A$. tridentata swales. The effect of enhanced precipitation on end-of-season soil water storage and profile patterns was negligible. Soil water storage was negatively correlated with the number and size of nearby plants. Root biomass was highest near the surface and decreased with depth down to $2 \mathrm{~m}$. The root biomass under $G$. spinosa coppice dunes was 10 times greater than in sparsely vegetated swales or swales dominated by $A$. tridentata. Variability in soil water characteristics was more strongly associated with vegetation patterns than with topography. The swales dominated by $A$. tridentata were significantly drier than sparsely vegetated swales. This ecosystem can recycle at least two times normal precipitation to the atmosphere via evapotranspiration (Link et al. 1994c).

Ecophysiological observations were taken on $A$. tridentata and $G$. spinosa to assess how these plants respond to increasing seasonal drought (Link et al. 1995a). Observations of soil water content around individual shrubs suggested that there was less water at the shallow areas and more at the deeper areas around $G$. spinosa than around $A$. tridentata. Stem diameter dynamics revealed similar patterns for both species with diameter increases in the spring and diameter shrinkage in the summer. The final stem diameter was greater for $A$. tridentata than $G$. spinosa. Nondestructive whole plant leaf area measurements indicated that $A$. tridentata produced more leaf area than $G$. spinosa. Xylem pressure potential values were much lower by summer for.G. spinosa than for $A$. tridentata, an indication of significant osmotic adjustment. Net photosynthesis, stomatal conductance, and transpiration were maximal in the spring and declined thereafter for both species (Link et al. 1995a). 


\subsubsection{N Grass}

Comparative observations on $B$. tectorum and $P$. sandbergii were taken for phenological development, root and shoot characteristics, and water relations in the field (Link et al. 1990a). The sandy soil at this field site has a low water-holding capacity (Gee and Kirkham 1984). Stomatal conductance, transpiration, and xylem pressure potential data were collected for both species as water stress increased. Water stress developed earlier and to a greater degree in $P$. sandbergii than in $B$. tectorum. Xylem water potential was lower in $P$. sandbergii than in $B$. tectorum and the difference increased through the season. Stomatal conductance and transpiration were greater for $B$. tectorum than for $P$. sandbergii. Midday stomatal closure occurred later in the season and to a lesser degree for $B$. tectorum than for $P$. sandbergii. Alleviation of water stress by irrigation retarded phenological development in both species and delayed senescence by about 10 days. Alleviation of water stress also increased values of pre-dawn xylem pressure potential relative to stressed plants, although as the plants senesced, values decreased in the nonstressed plants (Link et al. 1990a).

\subsubsection{Artemisia/Pseudoroegneria Community}

A wildfire in August 1984 eliminated A. tridentata from a shrub-steppe community on the FitznerEberhardt Arid Lands Ecology (ALE) reserve. Pseudoroegneria spicata dominated the community in subsequent years. By comparing leaf area index and soil water storage on the burned site with an adjacent unburned site containing $A$. tridentata, Link et al. (1990b) tested the hypothesis that plant community structure controls soil moisture dynamics, and that wildfire can alter the water balance in these arid landscapes. Elimination of $A$. tridentata from the landscape greatly reduced the community leaf area index. Soil water storage computed to a depth of $125 \mathrm{~cm}$ was not affected by the change in community structure. However, storage computed to a depth of $275 \mathrm{~cm}$ was significantly greater on the burned site compared to the unburned site. This difference increased with time. The leaf area index of these communities was positively correlated with soil water storage. Wildfire in shrub-steppe communities dominated by $A$. tridentata effectively removes the deep-rooted, woody component from these ecosystems. Consequently, the ability of the vegetation to remove stored soil water is inhibited by a reduction in the ability to access deeply stored soil moisture (Link et al. 1990b).

Ecophysiological characteristics, including transpiration, of $A$. tridentata were observed during an irrigation experiment to investigate the physiological mechanisms associated with flowering (Evans et al. 1991). Xylem pressure potential of stems at pre-dawn ranged from -3 in June to -5 MPa in August to October. The lowest reported value was $-5.38 \mathrm{MPa}$ in August. Leaf transpiration rates decreased from $10.6 \mu \mathrm{mol} \mathrm{g}^{-1} \mathrm{~s}^{-1}$ in July to $6.8 \mu \mathrm{mol} \mathrm{g}^{-1} \mathrm{~s}^{-1}$ in August (Evans et al. 1991).

\subsubsection{Lower Snively Field}

Large plants remove more water from the soil than do small plants. Growth rates and biomass of B. tectorum were investigated at Lower Snively field in relation to water, nitrogen, and temperature by Uresk et al. (1979). Soil temperature and plant tissue nitrogen showed a strong relation with growth rates from initiation of growth to peak production. After peak production, soil temperature was related 
to declining growth rates. Water stored in the soil profile had a weak relationship with growth rates. A simple model was developed, relating growth rates to soil temperature and plant tissue nitrogen (Uresk et al. 1979). Plant water uptake depends not only on the evaporative demand and stomatal conductance, but also on the ability of the plant to transmit water through its vascular system. Downs et al. (1991a) measured the hydraulic resistance of $B$. tectorum in Lower Snively soils as the plant aged, and found that hydraulic resistance increases with age.

The effect of water and nitrogen on $B$. tectorum was investigated over a growing season from November to May (Link et al. 1992a). The relationship between water, nitrogen, and growth must be determined in order to predict plant size. Plant size is positively correlated with transpiration in B. tectorum (Link et al. 1992a). A measure of plant size on a community scale is the leaf area index, a variable used in predicting transpiration. Leaf area index ranged from a maximum of 5.5 in the nitrogen plus water treatment to a minimum of between 1 and 2 in the nitrogen, water, and control treatments (Link et al. 1992a). Similar effects of water and nitrogen on B. tectorum were observed in the laboratory, where the only significant effects occurred when both water and nitrogen were added (Link et al. 1995b).

Another study was conducted between Lower and Upper Snively fields to develop a model of B. tectorum gas exchange for predicting transpiration (Link et al. 1992a). Data were gathered at the community scale inside a 30-cm-diameter chamber. Relationships between stomatal conductance and net photosynthesis, and the driving variables of light, vapor pressure gradient, temperature, and xylem pressure potential were parameterized. Equations successfully predicted transpiration for two days in June (Link et al. 1992a).

\subsubsection{Lysimeter Studies}

Lysimeters are soil-filled containers of various sizes and configurations and are used to measure water flow through soil (Gee et al. 1992). Lysimeter studies were initiated at Hanford in the 200 East area in 1971 using two 18-m-deep containers, one open at the bottom and the other closed. They were filled with sandy soil, and were probably populated by $S$. kali (Gee et al. 1992). Detailed records of vegetation were not kept in early studies, but Gee et al. (1992) conclude that they were vegetated during much of their history. Recharge rates were estimated to be $<2 \mathrm{~mm} \mathrm{y}^{-1}$ (Routson and Johnson 1990) and $5 \mathrm{~mm} \mathrm{y}^{-1}$ (Jones 1978), suggesting that they were vegetated. In contrast, recharge rates have been measured as high as $204 \mathrm{~mm} \mathrm{y}^{-1}$ in gravel-covered lysimeters without plants (Waugh et al. 1991). Fayer et al. (1986) simulated the lysimeters using an estimated plant cover of up to $30 \%$ and a rooting depth of $3 \mathrm{~m}$, and concluded that plants extract significant amounts of water. Their estimate of soil water storage was small, suggesting no recharge, and was very close to an observed value obtained in 1985 by Routson et al. (1988). This lysimeter had many scurf pea roots (Psoralea lanceolata) near the surface (Gee et al. 1992).

The effect of plants on soil water dynamics was investigated in sand-filled lysimeters at the Buried Waste Test Facility from 1985 to 1989 (Rockhold et al. 1990, Gee et al. 1992). Without plants, recharge ranged from 111 to $40 \mathrm{~mm} \mathrm{y}^{-1}$. When the lysimeters were planted with $B$. tectorum, recharge 
was measured at $62 \mathrm{~mm} \mathrm{y}^{-1}$, and when planted with $S$. kali, recharge ranged from 10 to $0 \mathrm{~mm} \mathrm{y}^{-1}$. Recharge is higher with $B$. tectorum than with $S$. kali because $S$. kali is deep-rooted and able to make use of nearly all stored water, while $B$. tectorum is shallow-rooted and thus unable to access as much water (Gee et al. 1992).

\section{ALE Lysimeters}

Soil water dynamics have been observed since 1986 using lysimeters on the ALE reserve. The lysimeters are located at an elevation of $300 \mathrm{~m}$.a.s.l. and receive an average precipitation of $230 \mathrm{~mm}$, which is $42 \%$ higher than in the 200 Areas Plateau. Soils are silt-loam. Two of the lysimeters were vegetated with an undisturbed community in which $A$. tridentata was the dominant species. Two other lysimeters were dominated by $P$. spicata. From 1987 to 1990 there has not been any recharge in these lysimeters (Campbell 1991). The dominant species are deep-rooted and occupy the entire soil volume of the lysimeters (1.5 m deep) (Gee et al. 1991, Gee et al. 1992).

\section{FLTF Lysimeters}

The Field Lysimeter Test Facility (FLTF) is located near the Hanford Meteorological Station and was designed to evaluate engineered soil and plant covers for barriers (Gee et al. 1989; Campbell et al. 1990). Planted vegetation is similar to that of McGee Ranch and is dominated by $A$. tridentata, $B$. tectorum, O. hymenoides, and $P$. sandbergii. Through 1992 there was not any drainage from vegetated or bare lysimeters, even under enhanced precipitation of $320 \mathrm{~mm} \mathrm{y}^{-1}$ (Campbell and Gee 1990b, Gee et al. 1992). Vegetated lysimeters extract significantly more water from the soil reserve than does soil evaporation alone (Gee 1993).

An effort was made to separate plant transpiration from soil evaporation by measuring the transpiration rate of $A$. tridentata with a stem flow gauge. Flow rates or transpiration rates were obtained diurnally for several days in the summer. The highest rate was between 15 and $20 \mathrm{~g} \mathrm{H}_{2} \mathrm{O} \mathrm{h}^{-1}$ (Link et al. 1992a).

Two simulation models were compared for their ability to predict soil water storage dynamics with and without $A$. tridentata in weighing lysimeters: the soil water infiltration and movement (SWIM), and the simulation of production and utilization of rangelands (SPUR-91) models (Link et al. 1993). These models made adequate predictions. The range of root mean square error values for the two models was 7.0 to 19.8. This compares well with the range reported by Fayer et al. (1992) for the bare soil data sets of 8.1 to 22.1 .

\section{Small-Tube Lysimeters}

The small-tube lysimeter (STLF) experiments were designed to test the effects and interactions among soil surface conditions, vegetation, and different levels of precipitation on soil water balance in a simulated isolation barrier system. The design of the lysimeters allows for quantitative measurement of soil water storage, evapotranspiration, and deep drainage over time, and for instantaneous, real-time 
measurements of evapotranspiration. Results of some of these experiments are summarized here, and described in detail in other publications (Link et al. 1992a, Waugh et al. 1991, Sackschewsky et al. 1993, Sackschewsky et al. 1995).

The small-tube lysimeter facility was constructed in the fall of 1988 , and soil water balance was monitored from its construction through the fall of 1992. Several concurrent experiments were conducted to test the effects of different erosion control practices, sand deposition on the surface, and different subsurface treatments, including alternative capillary break configurations and impermeable layers. The focus of this summary will be on how vegetation interacts with different erosion control practices and with different amounts of precipitation to affect the soil column water balance.

Each lysimeter is $169 \mathrm{~cm}$ long, with a 30.4-cm-internal-diameter (ID) well casing fitted with an endcap at the bottom and an aluminum lifting collar at the top. The entire lysimeter is placed vertically inside a 35.6-cm-ID PVC tube. Water storage changes are determined by weighing the lysimeter and calculating the difference between the current weight and the initial weight. Drainage is determined by collecting water from a small polymer tube fitted to a threaded drain hole in the end-cap at the bottom of the lysimeter. Evapotranspiration (ET) is calculated as a residual from the equation: $E T=P-S-D$, where $P$ is the total water input, $S$ is the change in water storage, and $D$ is drainage. The lysimeters were filled by hand, starting with a $15-\mathrm{cm}$ drainage layer graded from $1-\mathrm{cm}$ pea gravel at the bottom to $1.27-$ to $0.85-\mathrm{mm}$ sand at the top. Overlying the drainage layer is $1.5 \mathrm{~m}$ of silt-loam soil. The interface between the sand and the silt forms the capillary break portion of the simulated isolation barrier.

Three different soil surface configurations were evaluated: plain soil, a gravel mulch, and a gravel admixture. In the gravel mulch treatment lysimeters, the upper $7 \mathrm{~cm}$ of soil were replaced with a layer of gravel ( 1 to $3 \mathrm{~cm}$ in diameter). In the gravel admix treatment lysimeters, $30 \%$ (by weight) gravel was uniformally mixed into the upper $20 \mathrm{~cm}$ of soil prior to placement in the lysimeters. One half of the lysimeters received only ambient precipitation, and the other half received ambient precipitation plus regular supplemental irrigation to bring the total water input up to 2 times the normal monthly average precipitation during the first 2 years or 3 times the normal biweeky precipitation during the last 2 years. One-half of each of the surface configuration X precipitation treatment lysimeters were kept free of vegetation and the other half were planted with $B$. tectorum during the fall in 1989 and 1990 . The $B$. tectorum successfully reseeded itself in the vegetated lysimeters during 1991 and 1992 . The overall experiment was a $3 \times 2 \times 2$ factorial design, with five replicates of each surface configuration, $X$ precipitation $\mathrm{X}$ vegetation, treatment combination.

The changes in soil column water storage over time are shown in Figure 2.1, and the results of the analysis of variance of storage change, total ET, and cumulative drainage at the end of the experiment are presented in Table 2.4. All three of the main treatments (surface configuration, vegetation, and precipitation) significantly affected the soil water balance. Surface configuration had the greatest effect, primarily because the gravel mulch lysimeters had significantly lower evapotranspiration rates and comparably higher storage values than the comparable plain soil or admix lysimeters. The plain soil and admix treatments were not significantly different within any particular precipitation $\mathrm{X}$ vegetation treatment combination. Irrigation greatly increased total evapotranspiration in all of the surface 


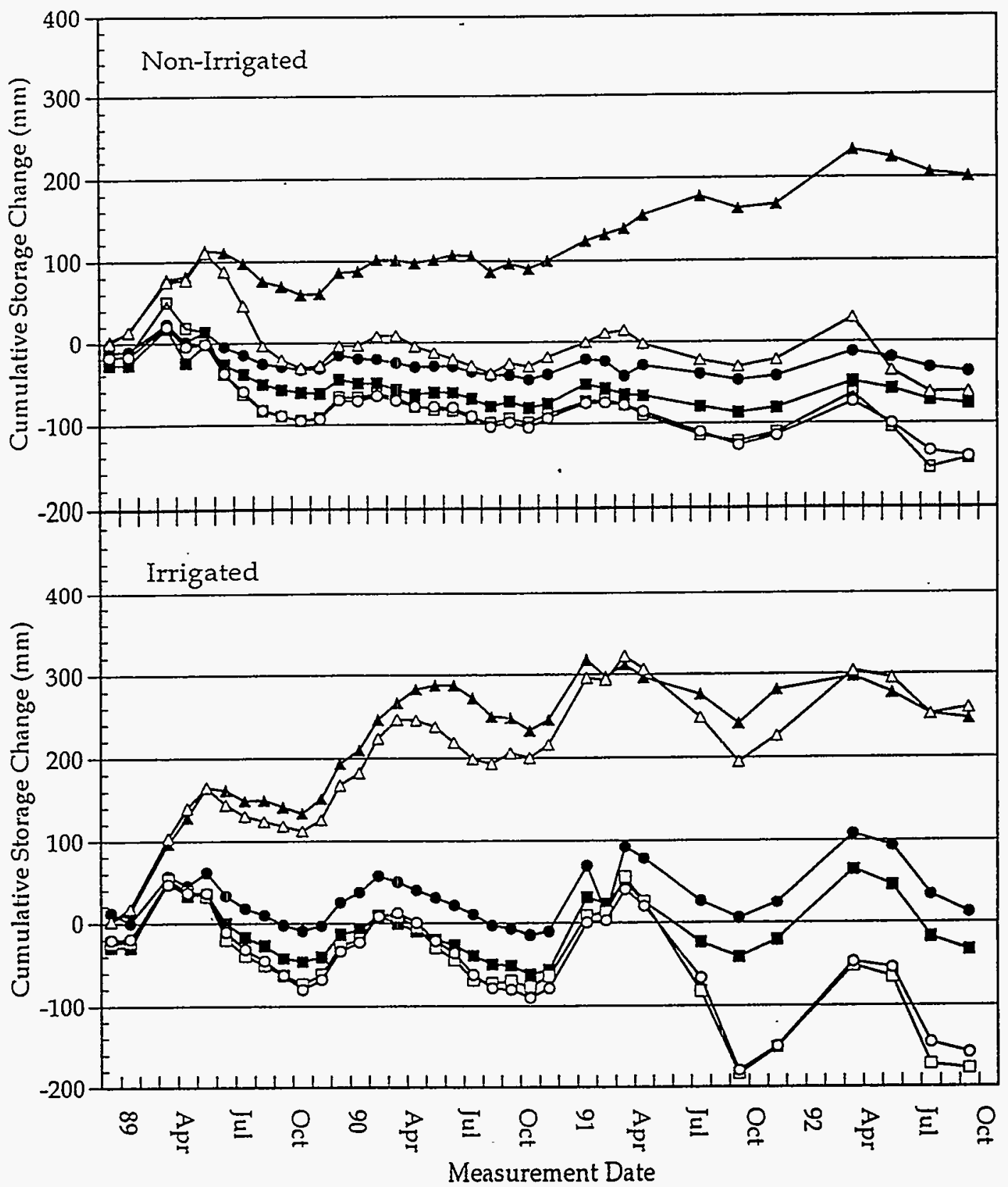

\begin{tabular}{ll|}
$\rightarrow-$ Soil - Bare & $-\square$ Soil - Cheatgrass \\
$\rightarrow-$ Admix - Bare & $-\neg$ Admix - Cheatgrass \\
$\rightarrow$ Gravel - Bare & $\rightarrow-$ Gravel - Cheatgrass
\end{tabular}

Figure 2.1. Cumulative Storage Change in the Small-Tube Lysimeters 
Table 2.4. Results of Analysis of Variance for Storage Change, Evapotranspiration, and Drainage in the Small-Tube Lysimeters

\begin{tabular}{|c|c|c|c|c|c|}
\hline \multicolumn{3}{|c|}{ Treatment Combination } & \multicolumn{3}{|c|}{$\begin{array}{c}\text { Cumulative Amount (mm) } \\
\text { (Mean } \pm 1 \text { s.e.) }\end{array}$} \\
\hline Surface & Irrigation & Vegetation & Storage & $\mathbf{E T}$ & Drainage \\
\hline Soil & Ambient & Bare & $-77 \pm 19(a b c)$ & $720 \pm 19(b)$ & $0 \pm 0 \quad$ (a) \\
\hline Soil & Ambient & Cheatgrass & $-144 \pm 6(a b)$ & $788 \pm 6(b)$ & $0 \pm 0$ \\
\hline Soil & Irrigated & Bare & $-33 \pm 21(b c)$ & $1594 \pm 21(\mathrm{~d})$ & $0 \pm 0 \quad$ (a) \\
\hline Soil & Irrigated & Cheatgrass & $-177 \pm 27 \quad$ (a) & $1738 \pm 27(e)$ & $0 \pm 0$ \\
\hline Admix & Ambient & Bare & $-38 \pm 12(\mathrm{bc})$ & $682 \pm 12(b)$ & $0 \pm 0 \quad$ (a) \\
\hline Admix & Ambient & Cheatgrass & $-141 \pm 20(a b)$ & $785 \pm 20(b)$ & $0 \pm 0 \quad$ (a) \\
\hline Admix & Irrigated & Bare & $12 \pm 37 \quad$ (c) & $1548 \pm 37(d)$ & $0 \pm 0 \quad$ (a) \\
\hline Admix & Irrigated & Cheatgrass & $-158 \pm 11(\mathrm{ab})$ & $1718 \pm 10(e)$ & $0 \pm 0 \quad$ (a) \\
\hline Gravel & Ambient & Bare & $201 \pm 44 \quad(d)$ & $431 \pm 38(a)$ & $12 \pm 7 \quad(a)$ \\
\hline Gravel & Ambient & Cheatgrass & $-62 \pm 18(a b c)$ & $708 \pm 19(\mathrm{~b})$ & $0 \pm 0 \quad$ (a) \\
\hline Gravel & Irrigated & Bare & $247 \pm 45 \quad(d)$ & $1237 \pm 15(\mathrm{c})$ & $77 \pm 31$ (b) \\
\hline Gravel & Irrigated & Cheatgrass & $260 \pm 11 \quad$ (d) & $1271 \pm 14(c)$ & $30 \pm 10(a b)$ \\
\hline
\end{tabular}

configuration $\mathrm{X}$ vegetation treatment combinations, but had a significant effect on storage in only the vegetated, gravel mulch lysimeters. In the plain soil and gravel admix lysimeters, vegetation had a significant effect on ET and storage when irrigated, but not in the ambient conditions. In the gravel mulch lysimeters, B. tectorum significantly increased ET and decreased storage under ambient conditions but had no significant effect under irrigated conditions. The only lysimeters that produced drainage had a gravel mulch surface. Drainage was not detected in any of the lysimeters with a plain soil or gravel admix surface, or from the ambient gravel mulch lysimeters.

Vegetation in the small-tube lysimeters increased evapotranspiration and decreased soil column water storage. In the gravel mulch treatments, the presence of plants also decreased the amount of drainage produced. It is expected that if a perennial bunchgrasses were used in place of $B$. tectorum, the overall effects of plants on the system would be increased because these plants are capable of extracting moisture from deeper soil layers (Link et al. 1990a and 1990b). 
Gaseous loss of water from the lysimeters by soil evaporation and plant transpiration (evapotranspiration) was measured using gas exchange equipment (Link et al. 1992b) to determine the effect of surface soil characteristics on evapotranspiration. The gas exchange chamber covered the entire surface of the lysimeters and could control internal temperature and relative humidity. This device permitted measurement of evapotranspiration, transpiration, and carbon dioxide exchange rates from lysimeters with various surface and plant characteristics. The effect on gas exchange rates was tested for sand, gravel, admix, and soil surfaces in vegetated (B. tectorum) lysimeters.

Evapotranspiration was unaffected by the surface treatments. Estimated transpiration rates were higher for plants growing in sand compared with rates for plants growing in the admix and soil treatments. Evapotranspiration rates were positively and linearly correlated with leaf area. Carbon dioxide exchange rates were positive (net photosynthesis $>0$ ) with $B$. tectorum and negative (soil respiration) without plants. These rates were significantly different (Link et al. 1992b).

\subsection{Soil Erosion}

Dry, bare soil surfaces are quickly eroded without plant or litter cover. Numerous studies were conducted to examine ways in which wind and water degrade both vegetated and barren barrier surfaces.

\subsubsection{Erosion by Water}

Water erosion can quickly degrade a barrier surface by establishing conditions for sheet runoff and gully formation. Gully formation will severely compromise a barrier. Water erosion can be controlled by adding a rock layer on the barrier surface, which has the negative effect of increasing infiltration. The best way to minimize water erosion is to maintain a vegetative cover, which is much less resistant to erosion than a rock cover and much more resistant than a cover of bare soil (DOE 1989). Foliage and plant litter resist water erosion by intercepting and absorbing rainfall energy (Gregory 1984) and preventing soil compaction from raindrops. Gregory (1984) developed equations to predict relative energy of raindrops reaching the soil surface that included terms for vegetative and litter cover as the primary predictors. Root systems bind soil particles, while litter filters sediment out of runoff. Aboveground plant litter increases surface roughness and slows runoff velocity. Roots and litter help maintain soil porosity and permeability, thereby increasing infiltration and decreasing runoff. Plants also dry the soil by transpiration, thereby delaying the onset of soil saturation and runoff (Gray and Leiser 1982).

Soil cryptogams (algae, mosses, and lichens) significantly influence water erosion, especially in arid and semi-arid environments (West 1990). Soil cryptogams reduce rainsplash erosion compared with bare soils (Tchoupopnou 1989). The binding of soil surface particles by cryptogams reduces sediment production, yet overland flow is increased because the soils are sealed (West 1990).

Water erosion studies at Hanford found that vegetation significantly reduced runoff in an A. tridentata/P. spicata community compared with plots where the vegetation had been clipped (Skaggs 
and Cadwell 1988). Vegetation reduced erosion by $82 \%$ to $96 \%$, compared with a bare plot, because of the reduction of raindrop energy (Gilmore and Walters 1993, Walters and Gilmore 1993).

\subsubsection{Erosion by Wind}

Wind erosion can quickly degrade a barrier surface by causing mass loss of fine soils at the barrier surface and development of dunes near irregularities on the surface. Loss of surface soils will compromise barrier function (Suter II et al. 1993). Vegetation is the key to controlling wind erosion in semi-arid and arid lands (Leys 1991). The breakup of microphytic soil crusts because of physical disturbance increases wind erosion (Marshall 1972). The loss of vegetative cover by fire is a leading cause of wind erosion in undisturbed ecosystems. It is anticipated that wind erosion will increase, through a decrease in plant cover, if climate conditions become hotter and dryer with global climate change (Muhs and Maat 1993).

Wind erosion is caused by wind turbulence interacting with the soil. A wind velocity profile follows a logarithmic function with height. Vegetative canopies determine the displacement height of the wind profile. Canopies reduce wind erosion by decreasing the energy of air parcels passing through the canopy. Equations used to predict soil losses from wind erosion include vegetative cover, litter cover, and height of the canopy above the soil as predictors (Gregory 1984). The use of wind tunnels to study wind erosion led to significant underestimates of erosional loss compared with field conditions (Leys 1991).

There has been little research into the effects of vegetation on wind erosion for barrier surfaces in the arid West. In the undisturbed shrub-steppe, there is little wind erosion because of stabilization of the surface by soil cryptogams. Fire can remove plant material and damage the cryptogams, leading to wind erosion. This has been observed in low elevation $A$. tridentata-P. sandbergii communities in sandy-loam soils at Hanford (Hinds and Sauer 1976). It has been suggested that the best way to prevent wind erosion in arid regions with relatively little vegetative cover is to cover the surface with a rock riprap (Voorhees et al. 1983). However, this would lead to increased infiltration to the waste because of reduced evapotranspiration.

Wind erosion studies have been carried out at Hanford to determine the amount of admix gravel needed to minimize erosion (Ligotke 1993) and to stabilize surfaces during revegetation (Cline and Uresk 1979). Admix gravels were found to significantly reduce wind erosion (Ligotke 1993). This finding is significant as a means of protecting the surface after fires burn the vegetation off barrier surfaces, or if vegetation is reduced because of hotter and drier climates. In a related study, Waugh et al. (1994c) found that admix gravel concentration on the surface (desert pavement) was greater on unvegetated plots than on vegetated plots and suggest this may be caused by greater deflation on the surface without plants. Cline and Uresk (1979) found surface treatments of straw, clay and straw/clay mixtures stabilized the soil sufficiently to resist wind erosion. This aided in establishing seeded B. tectorum stands, which further reduced wind erosion. Gaylord et al. (1993) investigated the migration of active sand dunes at Hanford (see location \#13 in Figure 1.2) and determined that there has been 
a $20 \%$ reduction in the volume of active sand dunes from 1948 to 1987 . This was attributed to changes in annual precipitation over the period. They hypothesize that increasing vegetative cover associated with increasing precipitation stabilizes these dunes (Gaylord et al. 1993). 


\subsection{Animals}

Animals have been recognized as agents that can burrow into buried waste and bring contaminated materials up to the surface. This was observed on the Hanford Site where an animal (most likely a badger) had tunneled (O'Farrell and Gilbert 1975) into radioactive salts $\left({ }^{90} \mathrm{Sr}\right.$ and ${ }^{137} \mathrm{Cs}$ ) that were subsequently ingested by black-tailed hares (Cline et al. 1980). Cline et al. (1980) demonstrated that intrusion, by roots, animals and ants, into buried waste could be prevented by placing a layer of loose rock covered with an asphalt emulsion between the buried waste and the topsoil. These authors cautioned, though, that intrusion can occur if soil is allowed to penetrate into the rock layer and create a pathway for roots and animals. Such penetration could happen over long periods of time.

Burrowing mammals investigated in barrier studies at Hanford include Perognathus parvus (Great Basin pocket mouse), Thomomys talpoides (northern pocket gopher), Spermophilus townsendii (Townsend ground squirrel), and Taxidea taxus (badger).

Studies on the effects of burrowing animals on permanent isolation surface barrier structures focused on three issues: 1) deep penetration of moisture through the fine soil layer, 2) accelerated erosion resulting from wind and water acting on exposed soil cast to the barrier surface by burrowing animals, and 3) the direct transport of contaminants that can occur as animals burrow through overlying barrier material and directly contact wastes (Cadwell et al. 1989). A test plan was written (Landeen et al. 1990) to address these technical issues. Three experimental approaches were used to resolve the issues. One approach was to contain small burrowing mammals in enclosures to study changes they might cause in water penetration and distribution within proposed barrier cover soils (Landeen et al. 1990). The second approach was to conduct field studies on free-ranging burrowing mammals to characterize their burrow systems and to evaluate how they influence the distribution of water in the soil profile. The third approach was to model the long-term redistribution of soil as a first order approximation to the potential for soil loss by wind and water erosion (Cadwell et al. 1989).

\subsection{Small Mammals}

Work activities and literature surveys on animal intrusion were conducted by Westinghouse Hanford Company in fiscal years 1988-1990. The work focused on small mammals and water storage. The objective of this task was to determine the degree to which small mammal burrow systems affect the loss or retention of water.

An animal intrusion lysimeter facility was constructed and installed in FY 1988. The facility consists of two outer boxes buried at grade that serve as receptacles for six animal intrusion lysimeters. At the beginning of each test, the lysimeters were lined with a 28-mil plastic liner and filled with a fine soil from McGee Ranch. Small burrowing animals common to the Hanford environs (pocket mice, pocket gophers, Townsend ground squirrels) were introduced over a 3- to 4-month period and allowed to burrow. During the course of each test, supplemental precipitation was added monthly to three of the 
lysimeters with a rainfall simulator, at a rate equivalent to a Hanford 100 -year storm. Soil moisture samples were taken before and after each test, while soil moisture measurements were taken with a hydroprobe during the test period.

Five tests (three in the summer, two in the winter) were completed during the study period. Information collected from the tests indicated the following: 1) during summer months, water was lost in all the lysimeters, including the supplemental precipitation added with the rainfall simulator; 2) during winter months, lysimeters with animals and controls.(no animals) gained water; and 3) long-term water storage did not appear to occur as a result of burrowing activity.

It was not possible to distinguish from the soil moisture profile graphs generated from any of the five tests which lysimeters contained animals and which lysimeters served as controls (no animals). If animal burrows at Hanford do facilitate the retention of water at depth, this was not observed as part of this study.

The lack of any significant water storage at depth and the overall water loss in the lysimeters occurred despite the following conditions that were imposed on the lysimeters: 1) no vegetative cover (no plant transpiration), 2) no water runoff (all water contained), 3) higher-than-normal animal and burrow densities, 4) supplemental precipitation added at rates not normally expected to occur, and 5) animals burrowing to the bottom of the lysimeters.

The data indicate that there is little difference in the amount of water stored between control and animal lysimeters. Initially, during high precipitation events when some burrows are open at the surface, water was able to infiltrate through the burrows faster and deeper than normal; however, within a relatively short time this excess water was removed. This was also observed in concurrent studies conducted at the Hanford Site regarding the effect of badger burrows on water distribution.

If this is the case, then the overall water loss must be attributed to processes that occur equally in control and treatment lysimeters (surface evaporation). Other variables, such as soil turnover and subsequent drying from burrowing activities and burrow ventilation, assist in removing soil moisture, but the overriding factor is soil evaporation resulting from high ambient temperatures during the spring and summer.

This study did not address all potential climate changes, runoff events, and potential effects of other burrowing animals. However, based upon the conditions imposed by the experimental design in this study and given the fact that a protective barrier will allow runoff, have a vegetative cover, and experience normal animal densities and normal precipitation events, small mammal burrowing effects regarding increased water storage at Hanford under the present climatic conditions appear to be negligible (Wing and Gee 1993). Studies conducted elsewhere in environments that receive more natural precipitation and have lower ambient temperatures may not produce results as pronounced as those observed at Hanford (Landeen 1994). 


\subsection{Medium-Size Mammals}

The badger (T. taxus), a Hanford Site mammal that is relatively large (several kilograms as opposed to mice and other small mammals that weigh a few tens of grams), was chosen for study because it is an extremely active burrowing mammal and is common on the Hanford Site. Badgers dig numerous holes in the process of hunting and thus have the potential to disturb barrier surface soils after vegetative covers become established on the soil surface and after other small mammals colonize the barrier. Studies focused on water infiltration through large mammal burrows.

Initial field studies of badger burrows (Cadwell et al. 1989) demonstrated that badger burrows are characterized by being up to $0.5 \mathrm{~m}$ deep, that they frequently have been dug in such a manner as to cause the cast soil to be mounded on the downhill side of the burrow opening (see Table 1, Cadwell et al. 1989), and that they frequently terminate below ground at an opening into the burrow of a small mammal that was being hunted by the badger. This led to the conclusion that runoff from precipitation could be directed into badger burrows, which might accumulate runoff and permit deep penetration of water in the fine-soil layer on the barrier surface.

Simulated rainfall on badger burrows and hand-constructed soil openings made to mimic badger burrows permitted further investigation of surface runoff accumulation. The results of this work clearly demonstrated that 1) runoff resulting from high intensity rainfall $\left(6.4 \mathrm{~cm} \mathrm{hr}^{-1}\right.$ applied for 30 minutes $)$ did collect in and completely fill both natural and simulated burrows. Conductivity probes inserted into the soil around and below the burrows showed water penetration to be approximately $50 \mathrm{~cm}$, or twice the average depth of the holes tested. Visual observations made when applying simulated rainfall suggested that water may enter badger burrows from three sources: direct entry of raindrops into the burrow opening; runoff water from the micro-watershed (cast soil mound immediately downslope from the burrow opening); and runoff-generated upslope.

Gravimetric measurement of soil water beneath 10 badger holes was made 4 days after an estimated $1.5 \mathrm{~cm}$ of rain fell in late May, 1988 (Cadwell et al. 1989). Rainfall penetrated to an average of $15 \mathrm{~cm}$ beyond the depth of the holes, or about $35 \mathrm{~cm}$ from the surface. The significance of this observation, however, is not the depth of water penetration, but rather the fact that natural rainfall caused a significant penetration of water beneath natural badger holes. The data suggested (see Figure 6 , Cadwell et al. 1989) that the natural rainfall resulting from that storm penetrated less than $5 \mathrm{~cm}$ from the soil surface in areas away from the badger burrows. These measurements confirmed that larger mammal burrows can and do cause the deep penetration of precipitation-generated runoff at Hanford. The deep soil moisture content near badger burrows, but below the wetting front caused by the rainfall event, was less than that for the control sites. This suggests a process by which soil water that penetrates through badger burrows might be preferentially removed.

A follow-up study was designed to measure soil moisture below badger burrows using a neutron probe. The study was designed to track soil moisture through time around burrows subsequent to the addition of simulated rainfall. Before applying the simulated rainfall, soil moisture at burrow sites was compared to that in control (no burrow) areas. Analysis of the data provided information identical to 
that obtained by gravimetric sampling of the natural burrows. The relationship was striking. The soil was consistently dryer beneath the burrows than it was at control locations for all depths measured $(15 \mathrm{~cm}, 45 \mathrm{~cm}$, and $95 \mathrm{~cm})$.

For the 1989 field season, soil moisture was tracked beneath badger burrow and at the same depths in control locations away from burrows. Figure 3.1 shows a summary of percent soil moisture difference between burrow locations and control locations. In March, which is normally the time when maximum soil moisture might be expected, soil moisture increases below burrows up to a depth of about $1 \mathrm{~m}$. The maximum difference in soil moisture at depth between the control site and near burrows was about $3.5 \%$. By June, the soil continued to dry to the point where soil near burrows was dryer (virtually all depths) than control soils except at depths below $1 \mathrm{~m}$. By September, virtually all depths showed depleted soil moisture near burrows. With the initiation of late fall and early winter rains (December curve), soil moisture began to return to the distribution displayed the previous March.

Although research demonstrated that badger holes do contribute to the deep penetration of surface water, measurements showed that soil moisture was, at certain times, significantly less under burrows than it was away from burrows. This anomaly appears to be explained by observations of plant growth near burrows. The vegetation in the study area (an abandoned old field) at the time of mid-summer soil moisture measurements, reported above, consisted primarily of $B$. tectorum that had completed its lifecycle and was uniformly dried and brown. The grass-covered field was, however, punctuated with an irregular spacing of large, green forbs consisting almost exclusively of $S$. altissimum. A closer inspection revealed that the forbs were located in disturbed soils at the burrow openings. Some of the individual plants had sprouted inside the burrow openings and were actually rooted several centimeters below the surface of the surrounding land area.

Rainfall may enter these burrows and penetrate deep into the soil profile. When this occurs, there is a subsequent invasion of annual plants in that disturbed and wetted soil. The hypothesis is that the reservoir of moisture along with the exposed soil provides an ideal habitat for the annual weedy plant species. Vegetation growing near the burrows has less competition and more available soil moisture than do plants growing elsewhere. The annual plants observed growing under those conditions were apparently able to develop a deep root system. Thus, it appears that the burrows that capture runoff and aid in its deep penetration also promote the vigorous growth of annual plants that subsequently remove the moisture by transpiration. Apparently, by the end of the growing season, the plants are able to deplete soil moisture to a greater extent than in areas distant from the burrows. It can be speculated that the cycle of alternating in soil wetting and drying (to the extent that annual precipitation is available to permit the process) in the vicinity of burrows continues until the burrows are filled by natural processes, which takes several years.

Ecologically, it is expected that a local abundance of a limiting resource, in this case soil moisture, would rapidly be used and therefore depleted. Thus, for the permanent isolation barrier, the local penetration of excess surface water does not appear to be a major cause for concern. It is anticipated that vegetation will routinely remove any excess soil moisture that accumulates near mammal burrows. Artificial rainfall applied to an old field, selected as a reasonable analog for a barrier surface (similar soils 


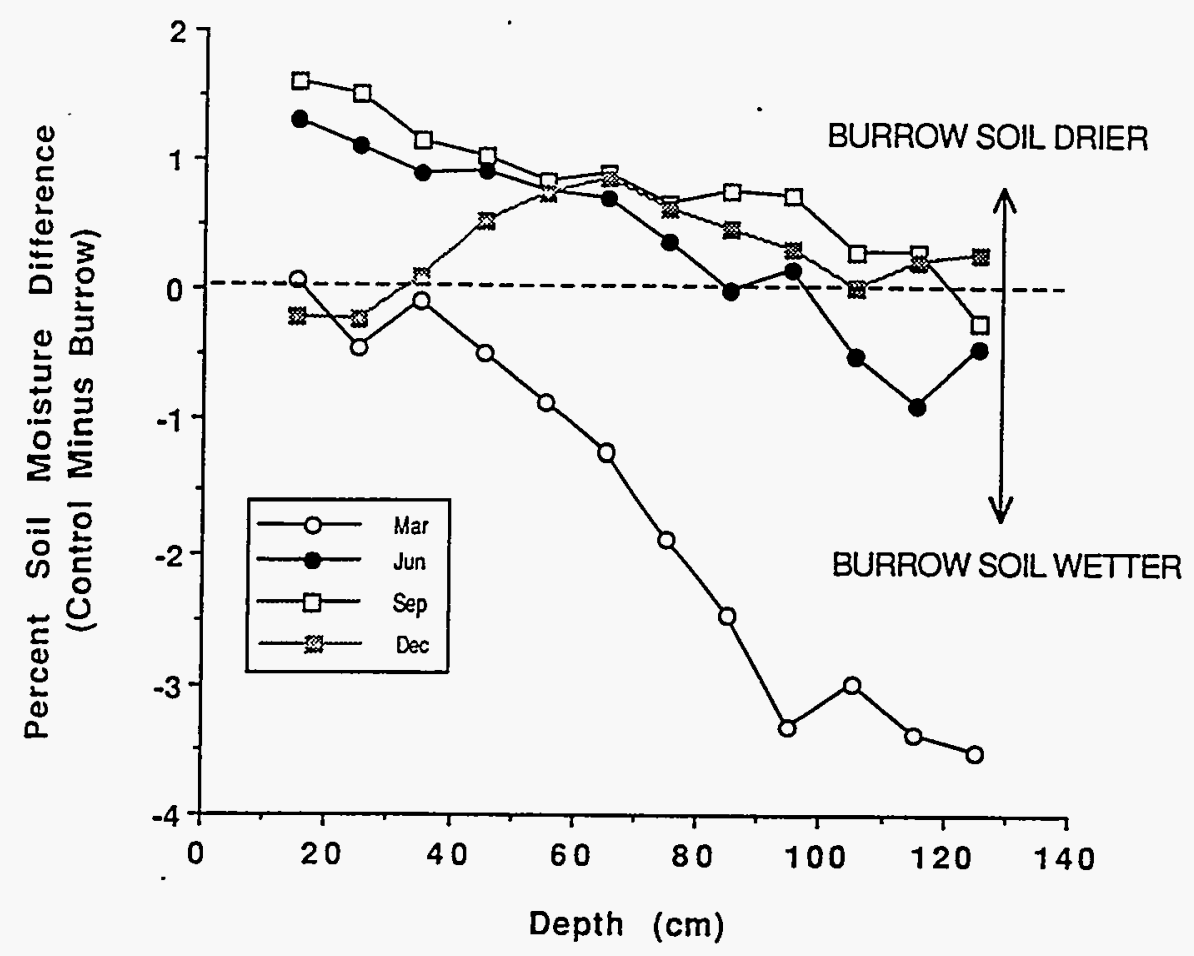

Figure 3.1. Mean Seasonal Percent Change in Soil Moisture Around Badger Burrows at the End of Each of the Four Calendar Quarters for 1989

and post-disturbance vegetation cover), during mid-summer, typically penetrated about $75 \mathrm{~cm}$ subsequent to a rainfall application likely to generate maximum runoff. The runoff intensity duplicated a storm having a 1000 year return frequency.

Barrier design criteria that permit capture and holding of annual surface water in $1.5 \mathrm{~m}$ or more of fine soil are not likely to be compromised by the temporary injection of runoff into large mammal openings. There appears to be a functional and compensating natural process that involves the invasion of plants having relatively deep root systems, which selectively and preferentially remove the excess soil water.

\subsection{Soil Moved to the Surface by Mammals}

The Hanford Barrier, having a long design life (thousands of years), will require protection from erosion. The barrier design must control erosion by wind and water, and must anticipate that future barrier surfaces will be occupied by animals whose burrowing may move easily erodible loose soil to the surface. Even very low rates of erosion, if occurring for an extended time, can reduce soil cover on barrier surfaces and affect barrier performance. Included in the Hanford Permanent Isolation Barrier Program Development program are studies that use gravels, either as surface mulches or mixed with the 
top soil, to control erosion. Animals can burrow, beneath the surface gravel and cast gravel-free soil to the surface. Hakonson et al. (1982) reported that in a single year one small-mammal species (pocket gopher, $T$. talpoides) inhabiting a low-level waste site at Los Alamos excavated about $12,000 \mathrm{~kg}$ of soil per hectare from a trench cover.

Buried contaminants associated with soil particles can be moved upward with soil cast during burrowing, or they may be exposed for transport by other means. There are numerous examples of contaminant transport, most involving radionuclides. For example, pocket mice excavated contaminated soil and moved it to the soil surface at a waste site that had previously been drained and covered . (Landeen and Mitchell 1982). Winsor and Whicker (1980) reported that pocket gophers (T. talpoides) moved plutonium to the soil surface, and they estimated that in a decade as much as $0.5 \%$ of the soil inventory may be cast to the surface. Small mammals also. carried transuranic radionuclides to the surface of a solid-waste disposal area in Idaho (Arthur and Markham 1983), and whitetail prairie dogs moved nuclear contaminants to the surface of a covered uranium mill-tailings pile in western Colorado (Shuman 1984). Deer mice that burrowed into a radioactive waste disposal area in Idaho became externally contaminated and carried radioactive materials above-ground, where the contamination was detected on their pelts and in body tissues (Arthur et al. 1987). Additional contamination was spread over the land surface through the animals' feces. O'Farrell and Gilbert (1975) reported that a mammal (probably a badger or coyote) burrowed into a waste crib at Hanford and exposed salts of cesium and strontium. Radioactive contaminants were then spread over a large area through feces and urine of hares (Lepus californicus) that apparently entered the open burrows and ingested the salt. Cadwell and Fitzner (1984) later found the same radionuclides in raptor castings (regurgitated pellets consisting of nondigestible remains of prey) near the burrow site and suggested that the contamination was the result of continued cycling of radionuclides originally exposed at the large-mammal burrow.

For each of the examples cited above, radioactivity was readily detected in the unconfined environment within a few years after waste burial. Kennedy et al. (1985) concluded that for landdisposal sites containing long-lived wastes, biological-transport processes, including animal burrowing, can result in significant exposure to future generations of human occupants. Other hazardous, nonnuclear materials that have long life expectancies can be moved from land-disposal sites by burrowing animals. Examples of radioactive-materials transport by burrowing animals are more abundant than are examples of other hazardous wastes because more intensive environmental surveillance has been conducted at nuclear waste sites, and because nuclear wastes are more easily detected through the radiation they emit. 


\subsection{Climate Change}

The interaction among design components and environmental and climatic factors is crucial to designing and testing protective barriers. Water movement within layered soil systems is closely tied to changes in surface soils, precipitation, temperature, and water extraction characteristics of plants. Changes in climate may also alter the structure of plant and animal communities inhabiting the area and, thus, the potential for biointrusion. Biointrusion studies may need to account for the influence of climate on plant-rooting depths and the regional distribution and behavior of burrowing animals. Changes in plant cover, burrowing animal behavior, precipitation and temperature, as well as wind regimes, may influence the stability of the barrier surface. At present, the possible future 1000-year variation in the climate and ecology of the Pasco Basin is largely unknown. If such a long time frame is to be considered, then more information must be obtained about the past and potential future range of key climatic variables. Global climates have undergone significant variations in the past, and there is every reason to expect that such variations will continue.

According to the Milankovitch theory, the Pleistocene ice ages were caused primarily by changes in the seasonal distribution of incoming radiation associated with orbit variations (Berger et al. 1984). Over the last 800,000 years, and possibly for as long as $2,000,000$ years, the earth has experienced a number of glacial cycles. Each lasted about 100,000 years, with a 10,000-year interglacial era (Hays et al. 1976, Kukla 1981, Berger et al. 1984). The last interglacial/glacial cycle started with a. 10,000-year interglacial (deep sea core oxygen isotope stage 5e) beginning about 125,000 years ago, immediately followed by a rapid growth of global ice sheets beginning 115,000 years ago. Glacial climate dominated the earth until about 12,000 years ago, when continental ice retreated from its most southern extent into what is now the state of Washington.

\subsection{Effects of Climate Change on Plants and Animals}

No vegetation or animal communities escaped the repeated stress of these climate and interglacial adjustments, and the Pasco Basin of south-central Washington is no exception. With each glacial cycle, the species displaced by climate, ice, water, and competition responded through growth form, migration or selection, or faced local extinction. Básed on the geophysical evidence of the past, there is a strong suggestion that we are cycling into the next glacial period (Imbrie and Imbrie 1980, Berger 1981, Berger et al. 1984).

As part of the Long-Term Climate Change Task of the Protective Barrier Program (Petersen et al. 1993), a full glacial pollen record was obtained from Carp Lake in south central Washington. Sediment cores were taken from the lake located in a volcanic cone $11 \mathrm{~km}$ north of Goldendale, Washington. Carp Lake has been previously cored to $8 \mathrm{~m}$, dating in excess of 33,000 years (Barnosky 1985). The new drilling operation recovered a $20.2-\mathrm{m}$ core. The age assignment of the core is based on 12 radiocarbon ages of bulk sediment and 11 volcanic tephra layers. Depending on the age model applied, the Carp Lake record ranges in age between 66,000 and 104,450 years. The most defensible age may 
be about 75,000 years. The pollen record is divided into nine assemblage zones that describe alterations between periods of montane conifer forest, pine forest, and steppe. Results from the Carp Lake pollen cores indicate that for the last approximately 75,000+ years, the climate for the Columbia River Basin was under the influence of Ice Age climates. Continental glaciers expanded out of the area that is now Canada toward the present-day Washington State, and the Columbia River Basin was much colder than it is currently. These conditions lasted up until about 12,000 years ago with little interruption.

During the last 10,000 years, the climate in the Columbia River Basin warmed significantly as the earth cycled out of the Ice Age and into climates more like the present. Periods (8000 to 6000 years ago) have existed that were as much as $2^{\circ} \mathrm{C}$ warmer than the Ice Age temperatures. Modern vegetation (and presumably modern-like climate) was established in the last 3900 years.

Other pollen records from the region complement the Carp Lake results. Thompson et al. (1993) conclude that 18,000 years ago, temperatures were below present levels everywhere in the Western United States, and increasingly colder toward the center of the continent. The Pacific Northwest was thus colder and also dryer than present. The presence of an ice sheet over Canada had profound effects on circulation. The anticyclone generated by the ice sheet brought dry prevailing easterlies to the Pacific Northwest region instead of the moisture-bearing prevailing westerlies. Contraction of the ice sheet and increasing summer insolation brought large-scale adjustments in circulation, accompanied by general warming.

In addition, Chatters (1989, 1991, Chatters and Hoover 1986, 1992, and Chatters et al. 1991) reviews the work of Baker (1983), Barnosky et al. (1987), and Mehringer (1985), among others, and summarizes the evidence for climatic and ecological change in the Hanford Site region of the Columbia Basin for the last 10,000 years or so. Chatters concludes that the period between 10,000 and 8500 years ago was characterized by a period of warmer-than-modern summers, colder-than-modern winters and low, spring-dominant precipitation, supporting extensive grasslands in Southeastern Washington in areas that are now dominated by sagebrush steppe. By 8000 years ago summer and winter were both relatively warm, and precipitation was at least $33 \%$ below modern levels. This climate pattern resulted in reduced stream flows with late spring flow maxima and extensive development of shrub-steppe vegetation throughout most of the region.

Chatters further characterizes the effect the warmer climate of 6000 and 8000 years ago had on streams and rivers of the region:

- stream flows were less than $70 \%$ modern;

- many small, low elevation, perennial streams became intermittent (dry during part of the year);

- streams had finer bed loads (greater sedimentation); 
- water temperatures were higher; and

- the spring peak flow (freshet) ended three to four weeks earlier than it does today.

Chatters indicates the climate cooled but remained dry between 5400 years and 4500 years ago, then underwent a period of transition to wetter, cooler conditions between 4500 years and 3900 years ago. Rivers flooded frequently, and forests expanded into steppe zones. From 3900 years until 2400 years ago the climate was cool in summer and cold in winter, with winter-dominant precipitation at least $30 \%$ above modern amounts. Alpine glaciers underwent the first synchronous advance of the Holocene. Rivers stabilized, and their peak flows were delayed into mid-summer; steppe vegetation increased in density as subalpine and probably montane forests expanded beyond their modern margins. Warmer, dryer conditions returned between 2400 years and 2000 years ago, reducing vegetation density and renewing severe flooding. Climate then improved somewhat, and modern climates were established. The Little Ice Age (ca. 1300 - 1850), although evident in alpine cirques, had little apparent effect on regional environments except for a slight drying around 550 years ago.

\subsection{Predictions}

The current climate of the interior Pacific Northwest is characterized by relatively cold and wet winters with a secondary precipitation maximum (Pyke 1972, Quinn 1976). In the northwestern United States, lowland treeless areas with a winter and early spring secondary precipitation maximum are characterized by more deeply rooted shrubs such as sagebrush (Artemisia sp.), whereas areas with late spring or summer precipitation maximum are characterized by relatively shallow-rooted grasses (compare Figures 4.1 and 4.2), suggesting that spring precipitation in the northern Plains fosters grasses over sagebrush (Frenkle 1984, Gould and Shaw 1983, Kutchler 1964, Risser et al. 1981). At present, sagebrush occupies the vast expanses of the Intermountain West that receive winter and early spring precipitation and experience late summer drought (West 1979).

February through May is the period of spring growth, when most of the plant growth occurs, and when stored soil water is depleted most actively by transpiration. West of the continental divide, June through September is the period of lowest rainfall (Figure 4.1), a stressful time of the year for plants. With the return of the cool season, the first of October through January period is the time of autumnwinter growth, when precipitation exceeds evapotranspiration, and soil water storage occurs. Sagebrush, after loss of some leaves and reduced photosynthetic activity, is revitalized by the return of cool season precipitation and increases photosynthetic activity, and it is during this season that the plant flowers and sheds pollen (West 1979).

Grasses have roots concentrated near the soil surface and are able to take advantage of the abundant precipitation during their growing season, but are also adapted to withstand a pronounced dry season (the winter drought on the Plains or the summer drought in central California). In addition to the prairie, Figure 4.2 shows that the eastern and western flanks of the Rocky Mountains in the Pacific Northwest (as well as numerous small areas stretching from southeastern Washington to northeastern 


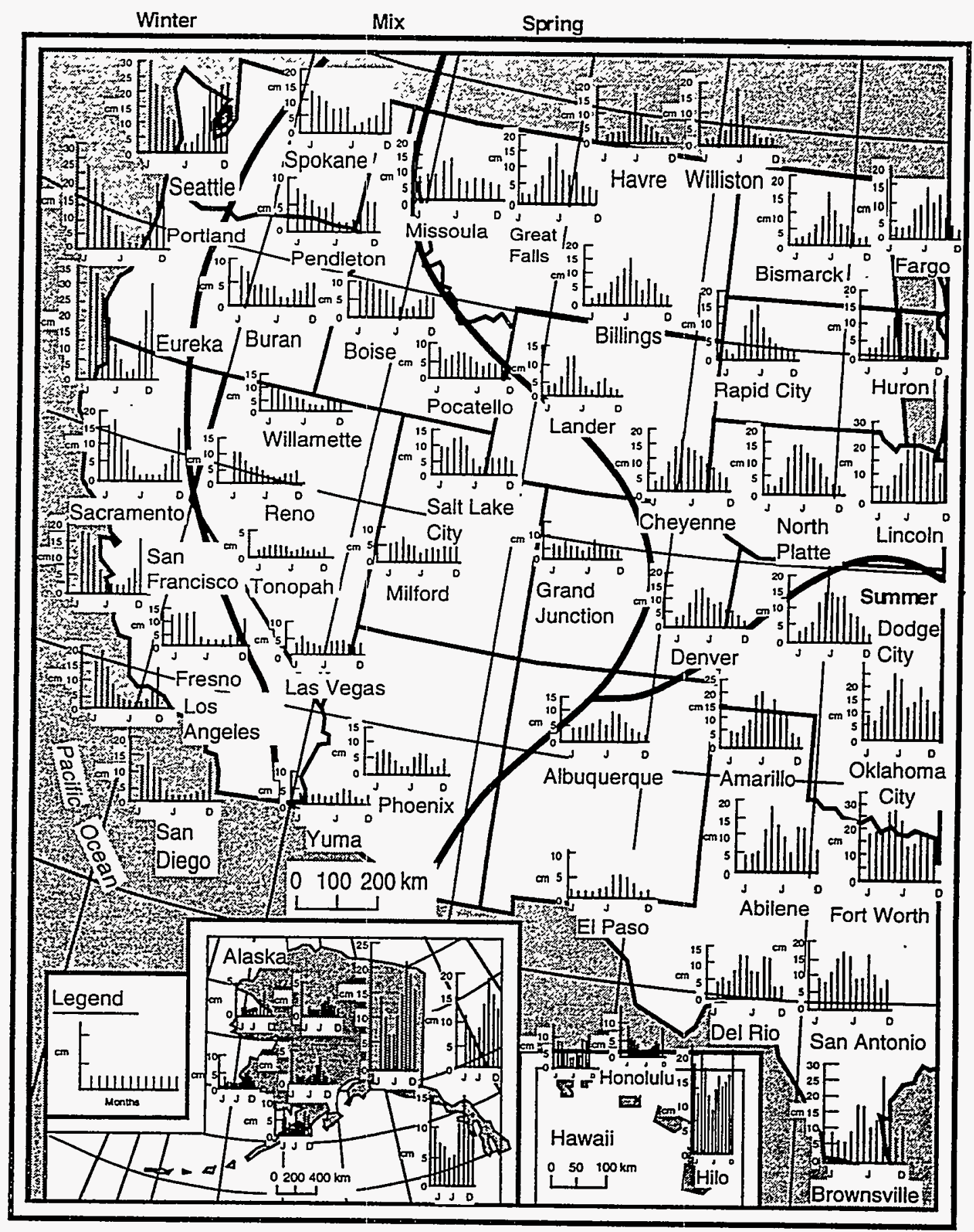

H9105011.2

Figure 4.1. Normal Monthly Average Precipitation (cm) for Selected Individual Weather Stations in the Western United States for the Period 1931-1960 (adapted from Ruffner and Bair 1977). Heavy lines mark areas with two contrasting patterns of winter precipitation; the winter precipitation maximum along the Pacific Coast and spring precipitation maximum over the northern plains. The intermediate area including eastern Washington and Oregon shows a mixture of the two patterns. 


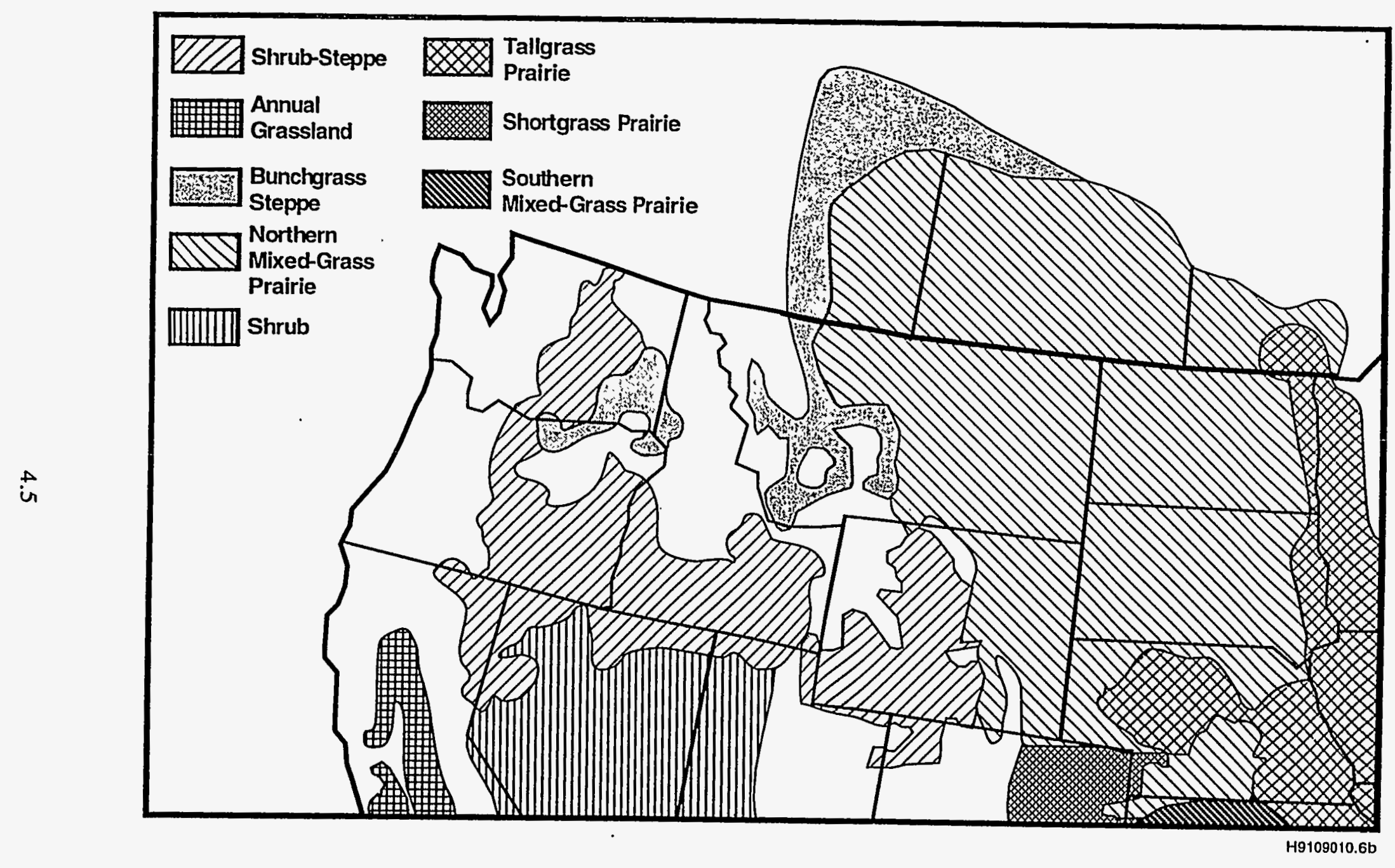

Figure 4.2. Major Grassland, Steppe and Shrub Types of Northwestern North America (adapted from Frenkle 1984, Gould and Shaw 1983, Kutchler 1964, and Risser et al. 1981) 
Utah) are characterized by bunchgrass steppe (Frenkle 1984, Gould and Shaw 1983, Kutchler 1964, Risser et al. 1981). Further west and south of the mapped Washington bunchgrass steppe (Figure 4.2), the bunchgrasses are joined by sagebrush to form the shrub-steppe whose southern boundary coincides with the southern extent of cloudy winter skies so characteristic of the Pacific Northwest (Frenkle 1984).

In contrast to grass, big sagebrush (A. tridentata) grows on deep, well-drained sandy or rocky soils that are not saline. Such soils tend to be droughty in mid-summer. Typically Pacific Northwest soils are wetted near the surface during the cool season by both rain or snowfall, and with the onset of warmer temperature begin to loose water at the surface through evapotranspiration. Because sagebrush does not loose its leaves in the fall, it is able to photosynthesize very early in the spring. When stressed by surface moisture shortage as the spring growing season moves into the midsummer drought period, the deep-rooted big sagebrush is able to mine water at depth and, at the height of the summer drought period and as discussed above, actually curtails its photosynthetic activity and sheds some leaves to reduce moisture loss (Caldwell 1979, Pearson 1975, Sturges 1979). All these characteristics give sagebrush an adaptive advantage over sod-forming grasses in areas where there is a pronounced summer drought, and allows it to coexist with Pacific Northwest bunchgrasses that are ideally suited to take advantage of the secondary spring maxima, and then die back during the summer drought.

As discussed above, fossil pollen analyses of eastern Washington indicate past alternating dominance between grass and sagebrush, suggesting that there have been past fluctuations in the strength of the late spring precipitation maximum in that region. Coatley (1979) and Ebbesmeyer et al. (1989) demonstrate that on a decadal scale there have been changes in the strength of the spring precipitation peak in the Columbia River Basin that may be attributable to sustained periods of dominance by either zonal general circulation flow (fostering more cold, continental-like climate) and favorable grasses over sagebrush, or more meridional flow (fostering more mild, coastal-like climate) fostering sagebrush at low, treeless elevation.

Human activity apparently is rivaling nature's ability to produce climatic change, judging by the potential impact of the increase of some gases in the atmosphere (Hansen et al. 1981, Schneider 1989). The current accumulation of carbon dioxide, methane, and other gases from the use of fossil fuels may lead to the warming of the lower atmosphere through a process dubbed the "greenhouse effect." Complex computer models suggest that global temperature will also increase, with estimates anywhere from $1.5^{\circ} \mathrm{C}$ to $4^{\circ} \mathrm{C}$ (Houghton et al. 1990,1992 ).

Regional studies for the Pacific Northwest are still developing, but good preliminary work is provided by Leovy and Sarachik (1991), Franklin et al. (1991), and Marks et al. (1993). Most of the models predict increased temperature (Houghton et al. 1990, 1992). However, the paleoclimate studies for eastern Washington discussed above provide a valuable analog, because temperatures then were judged to be slightly warmer and dryer. These conditions are similar to those predicted to be caused by increases in atmospheric concentrations of greenhouse gases, resulting in a rise of global temperatures by up to $3^{\circ} \mathrm{C}$ over the next 100 years (Houghton et al. 1990, 1992). 
As for changes in precipitation resulting from greenhouse warming, the models are not as consistent in their predictions for the next 100 years (Houghton et al: 1990, 1992, Crowley and North 1991). The warmer atmosphere will have a greater capacity to hold more water. This may mean the climate will be wetter, but some regions are likely to be dryer because of the greater evaporation potential. Calculations of changes in recharge rates must take into account the potential local effect of the greenhouse warming.

Figure 4.3 shows the predicted changes in vegetation distribution in eastern Washington that could accompany a change towards a more meridional general circulation pattern flow than the present, while Figure 4.4 shows the predicted changes under more zonal general circulation flow than the present.

Engineered vegetated soil caps to prevent precipitation from entering buried wasted may be affected by the type of vegetation growing on them. Future potential vegetation distribution for the region is important because studies show that under a cover of sagebrush there is significantly less soil water than under a cover of grass. This difference produces a stronger gradient in the upward flow of soil water and decreases the potential for water infiltration to the water table (Cline et al. 1977b, Link et al. 1990b, 1994b).

The potential future warming caused by the greenhouse effect ultimately will be overwhelmed by the plunge into the next ice age. In an important paper; Berger et al. (1991) review seven models of different complexity developed to predict the global climate for the next 10,000 to 100,000 years. All models are in relatively good agreement with the computation of astronomical forcing of climate change. In the absence of anthropogenic disturbances, the long-term cooling trend, which began some 6000 years ago, will continue for the next 5000 years. This will be followed by a stabilization at about 15,000 years, a cold interval centered at approximately 25,000 years, and finally by a major glaciation at about 55,000 years into the future. If, however, the Greenland ice sheet were to disappear in the next few centuries as a result of greenhouse warming, the northern hemisphere ice sheets would not reappear before 15,000 years from now and the climate would remain different from its natural evolution up to 65,000 years into the future, the maximum ice volume amounting to only $2 / 3$ of its naturally expected size at that time.

Winograd et al. (1992) has questioned the regular cyclic timing to date the pace of the ice ages (e.g., Berger et al. 1991, Hays et al. 1976). The Winograd research uses a well-dated and uninterrupted 500,000-year paleotemperature record contained in ${ }^{18} \mathrm{O}$ concentrations in calcite deposits below the water table in a Nevada crevasse called Devils Hole. Rather than a steady beat of interglacial-andice-age lasting a combined 110,000 years as predicted by celestial mechanics (e.g., Milankovitch theory), Winograd et al. found that, beginning at 420,000 years ago, the interglacial-and-ice-age had increasing lengths of $79,000,85,000,113,000$, and finally 128,000 years, providing an aperiodic swing to the climate cycle. The implication Winograd et al. sees for waste isolation is that the present interglacial may last another 10,000 years, and the maximum extent of the continental glacial ice (important for the Pasco Basin because of its potential for contributing to catastrophic flooding) may be reached 100,000 years or more into the future. 


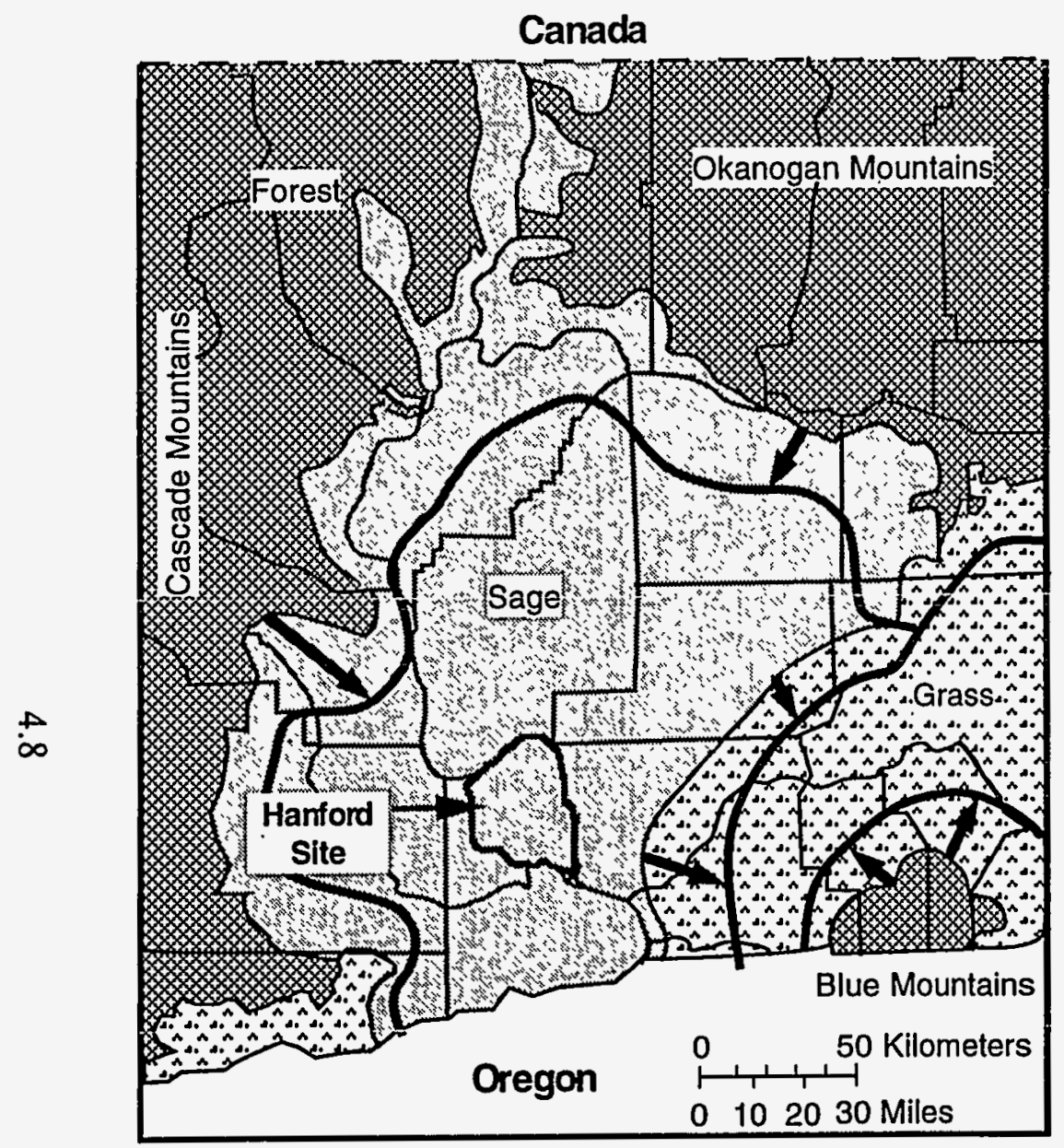

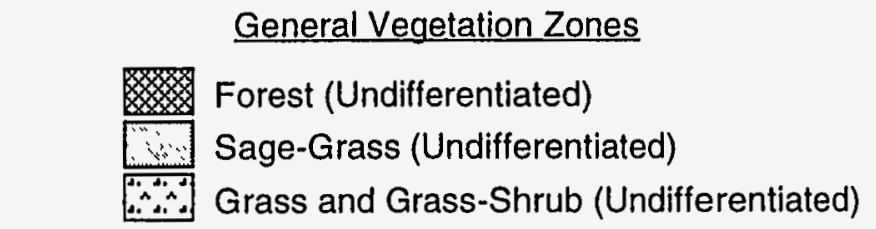



Figure 4.3. Predicted Vegetation and Precipitation Changes in Regions Surrounding the Hanford Site Under More Meridional Flow Conditions than at Present. The Hanford Site average monthly distribution of precipitation between 1912 and 1980 is from Stone et al. (1983) and the vegetation distribution is modified from Daubenmire (1970). 



Figure 4.4. Predicted Vegetation and Precipitation Changes in Regions Surrounding the Hanford Site Under More Zonal Flow Conditions than at Present. The Hanford Site average monthly distribution of precipitation between 1912 and 1980 is from Stone et al. (1983) and the vegetation distribution is modified from Daubenmire (1970). 


\subsection{Conclusions and Recommendations}

The optimal plant community for barrier function is one composed of deep-rooted perennial shrubs and grasses to minimize the risk of water drainage into the wastes and minimize erosion. The establishment of such a community in the face of the encroachment of invasive alien species is critical for proper barrier function. Investigations of the characteristics of new invasive alien species are needed. Continued research on community dynamics, rooting characteristics, transpiration, and the effects of plants on wind and water erosion is needed to gain confidence in barrier designs. This information needs to be integrated into simulation models of ecological processes to predict the ability of the barrier to function in the future under worst-case scenarios.

Little research has been done on the effects vegetation may have on infiltration of barrier surfaces. Infiltration depends on soil structure, which is determined by vegetation over time. This issue is most significant for sterile soils used on the surface of barriers. Over time these soils will become biologically active, changing their chemical makeup and hydrological characteristics, and they will undergo pedoturbation (Boul et al. 1980). There is a need to investigate the relationship between vegetation and soil development to properly understand soil physics and infiltration characteristics. Such investigations could be done in soil surfaces for which an age can be associated.

The role of nonvascular plants (soil cryptogamic crusts) in barrier function needs to be addressed in the context of vascular plant community dynamics, erosion, infiltration, and water budgets.

Conclusions drawn from animal studies indicate that small mammal burrows have little or no impact on soil moisture content. Larger animal burrows show an increase in soil water during the winter, but the soils near the large burrows dry out during the rest of the year because of increased evaporation and transpiration from weedy annuals growing on the disturbed soils (Cadwell et al. 1993). Thus, it is not likely that animals will compromise the water relations of the barrier. It should be cautioned, however, that this conclusion is based on short-term studies. More conclusive evidence of the effects of burrowing animals on plant community structure and water relations of barriers would require long-term studies or a wide range of field studies in natural analog sites. The problems regarding the impact of. burrowing animals on erosion have not been adequately addressed at Hanford.

Climate change studies indicate that the long-term mean annual precipitation in the Columbia River Basin is estimated to have ranged from $25 \%$ to $50 \%$ below to $28 \%$ above modern levels, while temperatures have ranged from $7{ }^{\circ} \mathrm{C}$ to $10^{\circ} \mathrm{C}$ below to $2^{\circ} \mathrm{C}$ above modern levels. Modern vegetation (and presumably modern-like climate) was established in the last 3900 years. The prediction for the future is that the present interglacial may last another 10,000 years, with the continental glacial ice reaching its maximum extent (important for the Pasco Basin because of its potential for contributing to catastrophic flooding) 100,000 years or more into the future. 
Confidence in the ability of isolation barriers to isolate hazardous wastes from dispersion into the environment will require long-term integrated studies. Such studies will have to develop an understanding of how ecosystems develop over time and how this will influence surface stability and hydrologic properties of barriers. 


\subsection{References}

Arthur, W. J., III, and O. D. Markham. 1983. Small Mammal Soil Burrowing as a Radionuclide Transport Vector at a Radioactive Waste Disposal Area in Southeastern Idaho. Journal of Environmental Quality 12:117-122.

Arthur, W. J., III, O. D. Markham, C. R. Groves, and B. L. Keller. 1987. Radionuclide Export by Deer Mice at a Solid Radioactive Waste Disposal Area in Southeastern Idaho. Health Physics 52:45-53.

Baker, R. G. 1983. Holocene Vegetational History of the Western United States. In The Holocene, ed. H. E. Wright, pp. 109-127. University of Minnesota Press, Minneapolis.

Barnosky, C. W. 1985. Late-Quaternary Vegetation in the Southwestern Columbia Basin, Washington. Quaternary Research 23:109-122.

Barnosky, C. W., P. M. Anderson, and P. J. Bartlein. 1987. The Northwestern U.S. During Deglaciation; Vegetation History and Paleoclimatic Implications. In North America and Adjacent Oceans During the Last Deglaciation, eds. W. F. Ruddiman and H. E. Wright, Jr, The Geology of North America, Volume K-3, pp. 289-321. Geological Society of America, Boulder, Colorado.

Berger, A. L. 1981. The Astronomical Theory of Paleoclimates. In Climatic Variations and Variability: Facts and Theories, ed. A. Berger, pp. 501-525. D. Reidel Publishing Company, Dordrecht, Holland.

Berger, A., J. Imbrie, J. Hays, G. Kukla, and B. Saltzman, eds. 1984. Milankovich and Climate. D. Reidel, Dordrecht, Holland.

Berger, A., H. Gallee, and J. L. Melice. 1991. The Earth's Future Climate at the Astronomical Timescale. In Future Climate Change and Radioactive Whaste Disposal: Proceedings of International Wrkshop, eds. G. M. Goodess and J. P. Palutikof, pp. 148-165. NSS/R257, U.K. Nirex Radioactive Waste Disposal, Ltd., Harwell, OX11 ORH, UK.

Boul, S. W., F. D. Hole, and R. J. McCracken. 1980. Soil Genesis and Classification. The Iowa State University Press, Ames, Iowa.

Brandt, C. A., W. H. Rickard, Jr., and M. G. Hefty. 1990. Interim Reclamation Report Basalt Waste Isolation Project Boreholes 1989. PNL-7280, Pacific Northwest Laboratory, Richland, Washington.

Brandt, C. A., and W. H. Rickard, Jr. 1990. Final Reclamation Report: Basalt Waste Exploratory Shaft Site. PNL-7379, Pacific Northwest Laboratory, Richland, Washington. 
Brandt, C. A., W. H. Rickard, Jr., and N. A. Cadoret. 1992. Basalt Waste Isolation Project Reclamation Support Project 1991-1992 Report. PNL-8151, Pacific Northwest Laboratory, Richland, Washington.

Brandt, C. A., and W. H. Rickard. 1994. Alien Taxa in the North American Shrub-Steppe Four Decades after Cessation of Livestock Grazing and Cultivation Agriculture. Biological Conservation 68:95-105.

Burt, C. J., and S. W. Cox. 1993. An Assessment of Plant Biointrusion on Six UMTRA Project Disposal Cells. In Waste Management '93-Proceedings of the 1995 Waste Management Conference, University of Arizona, Tucson, Arizona.

Cadwell, L. L., and R. E. Fitzner. 1984. Nuclear Fuel-Cycle Radionuclides in Raptor Castings: Implications for Environmental Monitoring. Health Physics 47:723-728.

Cadwell, L. L., L. E. Eberhardt, and M. A. Simmons. 1989. Animal Intrusion Studies for Protective Barriers: Status Report for FY 1988. PNL-6869, Pacific Northwest Laboratory, Richland, Washington.

Cadwell, L. L., L. E. Eberhardt, M. A. Simmons, and D. S. Landeen. 1993. Animal Intrusion Studies. In Hanford Site Protective Barrier Development Program: Fiscal Year 1993 Highlights, eds. L. L. Cadwell, S. O. Link, G. W. Gee, PNL-8741, Pacific Northwest Laboratory, Richland, Washington.

Caldwell, J. A. 1992. Engineering Perspectives for Near-Surface Disposal. In Deserts as Dumps? The Disposal of Hazardous Materials in Arid Ecosystems. eds. C. C. Reith and B. M. Thomson, pp. 161-198. University of New Mexico Press, Albuquerque, New Mexico.

Caldwell, M. M. 1979. Physiology of Sagebrush. In The Sagebrush Ecosystem: A Symposium, April 1978, pp. 74-85. College of Natural Resources, Utah State University, Logan.

Campbell, M. D. 1991. Field Lysimeter Test Facility. In Hanford Site Protective Barrier Development Program: Fiscal Year 1990 Highlights, ed. L. L. Cadwell, PNL-7831, Pacific Northwest Laboratory, Richland, Washington.

Campbell, M. D., and G. W. Gee. 1990. Field Lysimeter Test Facility: Protective Barrier Test Results (FY 1990, The Third Year). PNL-7558, Pacific Northwest Laboratory, Richland, Washington.

Campbell, M. D., G. W. Gee, M. J. Kanyid, and M. L. Rockhold. 1990. Field Lysimeter Test Facility: Second Year (FY 1989) Test Results. PNL-7902, Pacific Northwest Laboratory, Richland, Washington. 
Chatters, J. C. 1989. Appendix C: Ecology and Environmental History of the Hanford Site. In Hanford Cultural Resource Management Plan, ed. J. C. Chatters, pp. C.1-C.30. PNL-6942, Pacific Northwest Laboratory, Richland, Washington.

Chatters, J. C. 1991. Long-Term Climate Change Effects. In Hanford Site Protective Barrier Development Program: Fiscal Year 1990 Highlights, ed. L. L. Cadwell. PNL-7831, Pacific Northwest Laboratory, Richland, Washington.

Chatters, J. C., and K. A. Hoover. 1986. Changing Late Holocene Flooding Frequencies on the Columbia River, Washington. Quaternary Research 26:309-320.

Chatters, J. C., and K. A. Hoover. 1992. Response of the Columbia River Fluvial System to Holocene Climatic Change. Quaternary Research 37:42-59.

Chatters, J. C., D. A. Neitzel, M. J. Scott, and S. A. Shankle. 1991. Potential Impacts of Global Climate Change on Pacific Northwest Spring Chinook Salmon (Oncorhynchus tshawytscha): An Exploratory Case Study. The Northwest Environmental Journal 7:71-92.

Cline, J. F., D. W. Uresk, and W. H. Rickard. 1975. Characterization of Plant Communities Adjacent to the B-C Controlled Area and REDOX Pond Areas on the 200 Area Plateau. BNWL-1916, Pacific Northwest Laboratory, Richland, Washington.

Cline, J. F., D. W. Uresk, and W. H. Rickard. 1977a. Plants and Soil of a Sagebrush Community on the Hanford Reservation. Northwest Science 51:60-70.

Cline, J. F., D. W. Uresk, and W. H. Rickard. 1977b. Comparison of Soil Water used by a Sagebrush-Bunchgrass and a Cheatgrass Community. Journal of Range Management 30:199-201.

Cline, J. F., and V. A. Uresk. 1979. Revegetation of Disturbed Grounds in the Semi-Arid Climate of Southcentral Washington. Health Physics 36:289-294.

Cline, J. F., K. A. Gano, and L. E. Rogers. 1980. Loose Rock as Biobarriers in Shallow Land Burial. Health Physics 39:497-504.

Coatley, S. M. 1979. Climate Variability in the Pacific Northwest and its Effect on Stripe Rust Disease of Winter Wheat. Climatic Change 2:33-51.

Crowley, T. J., and G. R. North. 1991. Paleoclimatology. Oxford Monographs on Geology and Geophysics No. 16. Oxford University Press, New York.

Daubenmire, R. F. 1970. Steppe Vegetation of Washington. Technical Bulletin 62, Washington Agricultural Experiment Station, Pullman, Washington. 
Daubenmire, R. F. 1975. Plant Succession on Abandoned Fields, and Fire Influences, in a Steppe Area in Southeastern Washington. Northwest Science 49:36-48.

DOE (U.S. Department of Energy). 1989. Technical Approach Document: Revision II, UMTRADOE/Al-050425.0002, DOE UMTRA Project Office, Albuquerque Operations Office, Albuquerque, New Mexico.

Downs, J. L., S. O. Link, and R. A. Black. 1991a. Effects of Soil Water Deficit and Plant Age on Plant Water Uptake. In Pacific Northwest Laboratory Annual Report for 1990 to the DOE Office of Energy Research. Part 2. Environmental Sciences, ed. R. E. Wildung, pp. 72-74. PNL-7600 Pt. 2, Pacific Northwest Laboratory, Richland, Washington.

Downs, J. L., S. O. Link, L. L. Cadwell, and M. R. Sackschewsky. 1991b. Root Intrusion Studies: Design and Initial Samples. In Hanford Site Protective Barrier Development Program: Fiscal Year 1990 Highlights, ed. L. L. Cadwell, PNL-7831, Pacific Northwest Laboratory, Richland, Washington.

Downs, J. L., L. L. Cadwell, and S. O. Link. 1993. Root Intrusion, Root Distribution Studies. In Hanford Site Protective Barrier Development Program: Fiscal Year 1993 Highlights. eds. L. L. Cadwell, S. O. Link, and G. W. Gee, pp. 2.7-2.9. PNL-8741, Pacific Northwest Laboratory, Richland, Washington.

Ebbesmeyer, C. C., C. A. Coomes, G. A. Cannon, and D. E. Bretschneider. 1989. Linkage of Ocean and Fjord Dynamics at Decadal Period. In Aspects of Climate Variability in the Pacific and Western Americas, ed. D. H. Peterson, Geophysical Monograph 55, pp. 399-417. American Geophysical Union, Washington, D.C.

Evans, R. D., R. Alan Black, and S. O. Link. 1991. Reproductive Growth During Drought in Artemisia tridentata Nutt. Functional Ecology 5:676-683.

Fayer, M. J., G. W. Gee, and T. L. Jones. 1986. UNSAT-H Version 1.0: Unsaturated Flow Code Documentation and Applications for the Hanford Site. PNL-5899, Pacific Northwest Laboratory, Richland, Washington.

Fayer, M. J., M. L. Rockhold, and M. D. Campbell. 1992. Hydrologic Modeling of Protective Barriers: Comparison of Field Data and Simulation Results. Soil Sci. Soc. Amer. J. 56:690-700.

Fisher, J. N. 1986. Hydrogeologic Factors in the Selection of Shallow Land Burial for the Disposal of Low-Level Radioactive Waste. U.S. Geological Survey Circular 973.

Franklin, J. F., and C. T. Dyrness. 1973. Natural Vegetation of Oregon and Washington. Pacific Northwest Forest and Range Experiment Station, USDA Forest Service General Technical Report, PNW-8. 
Franklin, J. F., F. J. Swanson, M. E. Harmon, D. A. Perry, T. A. Spies, V. H. Dale, A. McKee, W. K. Ferrell, J. E. Means, S. V. Gregory, J. D. Lattin, T. D. Schowalter, and D. Larsen. 1991. Effects of Global Climatic Change on Forests in Northwestern North America. The Northwest Environmental Journal 7:233-254.

Frenkle, R. E. 1984. Vegetation. In Atlas of the Pacific Northwest, 7th edition, eds. A. J. Kimerling and P. L. Jackson, pp. 58-66. Oregon State University Press, Corvalis, Oregon.

Gaylord, D. R., L. D. Stetler, G. D. Smith, and R. W. Mars. 1993. Summary of 1990 Eolian Characterization Studies, Hanford Site, Washington. PNL-8862, Pacific Northwest Laboratory, Richland, Washington.

Gee, G. W. 1987. Recharge at the Hanford Site: Status Report. PNL-6403, Pacific Northwest Laboratory, Richland, Washington.

Gee, G. W. 1993. Field Lysimeter Test Facility. In Hanford Site Protective Barrier Development Program: Fiscal Year 1992 and 1993 Highlights, eds. L. L. Cadwell, S. O. Link, G. W. Gee, PNL-8741, Pacific Northwest Laboratory, Richland, Washington.

Gee, G. W., and R. R. Kirkham. 1984. Arid Site Water Balance: Evapotranspiration Modeling and Measurements. PNL-5177, Pacific Northwest Laboratory, Richland, Washington.

Gee, G. W., R. R. Kirkham, J. L. Downs, and M. D. Campbell. 1989. The Field Lysimeter Test Facility (FLTF) at the Hanford Site: Installation and Initial Tests. PNL-6810, Pacific Northwest Laboratory, Richland, Washington.

Gee, G. W., M. D. Campbell, and S. O. Link. 1991. Arid Site Water Balance using Monolith Lysimeters. In Lysimeters for Evapotranspiration and Environmental Measurement, ed. R. G. Allen, T. A. Howell, W. O. Pruitt, I. A. Walter, and M. E. Jensen, pp. 219-227. Proceedings of the International Symposium on Lysimetry, American Society of Civil Engineers, New York.

Gee, G. W., M. J. Fayer, M. L. Rockhold, and M. D. Campbell. 1992. Variations in Recharge at the Hanford Site. Northwest Science 92:237-250.

Gee, G. W., L. L. Cadwell, H. D. Freeman, M. W. Ligotke, S. O. Link, R. A. Romine, W. H. Walters, Jr., and N. R. Wing. 1993a. Testing and Monitoring Plan for the Permanent Isolation Surface Barrier Prototype. PNL-8391, Pacific Northwest Laboratory, Richland, Washington.

Gee, G. W., D. G. Felmy, J. C. Ritter, M. D. Campbell, J. L. Downs, M. J. Fayer, R. R. Kirkham, and S. O. Link. 1993b. Field Lysimeter Test Facility Status Report IV: FY 1993. PNL-8911, Pacific Northwest Laboratory, Richland, Washington. 
Gee, G. W., H. D. Freeman, W. H. Walters, M. W. Ligotke, M. D. Campbell, A. L. Ward, S. O. Link, S. K, Smith, B. G. Gilmore, and R. A. Romine. 1994. Hanford Prototype Surface Barrier Status Report: FY 1994. PNL-10275, Pacific Northwest Laboratory, Richland, Washington.

Gilmore, B. G., and W. H. Walters. 1993. Water Erosion Field Tests for Hanford Protective Barriers: FY 1992 Status Report. PNL-8949, Pacific Northwest Laboratory, Richland, Washington.

Gould, F. W., and R. B. Shaw. 1983. Grass Systematic, 2nd edition. Texas A\&M Press, College Station, Texas.

Gray, D. M., and A. T. Leiser. 1982. Biotechnical Slope Protection and Erosion Control. Von Nostrand Reinhold Co., Inc., New York, New York.

Gregory, J. M. 1984. Prediction of Soil Erosion by Water and Wind for Various Fractions of Cover. Transactions of the American Society of Agricultural Engineers 27:1345-1350.

Hajek, B. F. 1966. Soil Survey, Hanford Project in Benton County, Washington. BNWL-243, Pacific Northwest Laboratory, Richland, Washington.

Hakonson, T. E., G. L. DePoorter, W. V. Abeele, B. W. Burton, J. W. Nyhan, B. A. Perkins, and L. J. Lane. 1982. Remedial Action Technology - Arid. In Proceedings of the Fourth Annual Participants Information Meeting, U.S. Department of Energy Low-Level Waste Management Program, October 1982, pp. 685-702. ORNL/NFW-82/18, Oak Ridge National Laboratory, Oak Ridge, Tennessee.

Hakonson, T. E., L. J. Lane, and E. P. Springer. 1992. Biotic and Abiotic Processes. In Deserts as dumps? The Disposal of Hazardous Materials in Arid Ecosystems. eds. C. C. Reith and B. M. Thomson. pp. 101-146. University of New Mexico Press. Albuquerque, New Mexico.

Hansen, J., D. Johnson, A. Lacis, S. Lebedeff, P. Lee, D. Rind, and G. Russell. 1981. Climate Impact of Increasing Atmospheric Carbon Dioxide. Science 213:957-966.

Harris, G. A. 1967. Some Competitive Relationships Between Agropyron spicatum and Bromus tectorum.. Ecological Monographs 37:89-111.

Harris, G. A., and A. M. Wilson. 1970. Competition for Moisture among Seedlings of Annual and Perennial Grasses as Influenced by Root Elongation at Low Temperature. Ecology 51:25-37.

Hays, J. D., J. Imbrie, and N. J. Shackleton. 1976. Variations in the Earth's Orbit: Pacemakers of the Ice Ages. Science 194:1121-1132. 
Hinds, W. T., and R. H. Sauer. 1976. Soil Erodibility, Soil Erosion, and Revegetation Following Wildfire in a Shrub-Steppe Community. In Atmospheric-Surface Exchange of Particulate and Gaseous Pollutants. ERDA Symposium Series 38, CONF-740921.

Houghton, J. T., G. J. Jenkins, and J. J. Ephraums. 1990. Climate Change: The IPCC Scientific Assessment. Cambridge University Press, Cambridge, UK.

Houghton, J. T., B. A. Callander, and S. K. Varney. 1992. Climate Change 1992: The Supplementary Report to the IPCC Scientific Assessment. Cambridge University Press, Cambridge, UK.

Imbrie, J., and J. Z. Imbrie. 1980. Modeling the Climatic Response to Orbital Variations. Science 207:943-953.

Jones, T. L. 1978. Sediment Moisture Relations: Lysimeter Project 1976-1977 Water Year. RHO-ST-15, Rockwell Hanford Operations, Richland, Washington.

Kennedy, W. E., Jr., L. L. Cadwell, and D. H. McKenzie. 1985. Biotic Transport of Radionuclides from a Low-Level Radioactive Waste Site. Health Physics 47:723-728.

Klemmedson, J. O., and J. G. Smith. 1964. Cheatgrass, Bromus tectorum L. Botanical Review 30:226-262.

Klepper, B., L. E. Rogers, J. D. Hedlund, R. G. Schreckhise, and K. R. Price. 1978. Radiocesium Movement in a Gray Rabbit Brush Community. In Environmental Chemistry and Cycling Processes, Proceedings of Mineral Cycling Symp. eds. D. C. Adriano and I. L. Brisbin, pp. 725-737. CONF-760429, Atlanta.

Klepper, E. L., K. A. Gano, and L. L. Cadwell. 1985. Rooting Depth and Distributions of DeepRooted Plants in the 200 Area Control Zone of the Hanford Site. PNL-5247, Pacific Northwest Laboratory, Richland, Washington.

Kukla, G. J. 1981. Pleistocene Climates on Land. In Climate Variations and Variability: Facts and Theories, ed. A. Berger, pp. 207-232. D. Reidel Publishing Company, Dordrecht, Holland.

Kutchler, A. W. 1964. Potential Natural Vegetation of the Coterminous United States (map). American Geographical Society Special Publication, 36.

Landeen, D. S., and R. M. Mitchell. 1982. Intrusion of Radioactive Waste Burial Sites by the Great Basin Pocket Mouse (Perognathus parvus). RHO-SA-211, Rockwell Hanford Company, Richland, Washington.

Landeen, D. S., L. L. Cadwell, L. E. Eberhardt, R. E. Fitzner, and M. A. Simmons. 1990. Animal Intrusion Field Test Plan. WHC-EP-0253, Westinghouse Hanford Company, Richland, Washington. 
Landeen, D. S. 1994. The Influence of Small Mammal Burrowing Activity on Water Storage at the Hanford Site. WHC-EP-0730, Westinghouse Hanford Company, Richland, Washington.

Leovy, C., and E. S. Sarachik. 1991. Predicting Climate Change for the Pacific Northwest. The Northwest Environmental Journal 7:169-201.

Leys, J. F. 1991. Towards a Better Model of the Effect of Prostrate Vegetation Cover on Wind Erosion. Vegetation 91:49-58.

Ligotke, M. W. 1993. Soil Erosion Rates Caused by Wind and Saltating Sand Stresses. PNL-8478, Pacific Northwest Laboratory, Richland, Washington.

Link, S. O., P. A. Beedlow, and M. E. Thiede. 1988. The Effect of Perturbations to the Water and Nitrogen Cycles in Arid Land Ecosystems. In Pacific Northwest Laboratory Annual Report for 1987 to the DOE Office of Energy Research. Part 2. Environmental Sciences, ed. R. E. Wildung, pp. 4-7. PNL-6500 Pt. 2, Pacific Northwest Laboratory, Richland, Washington.

Link, S. O., G. W. Gee, and J. L. Downs. 1990a. The Effect of Water Stress on Phenological and Ecophysiological Characteristics of Cheatgrass and Sandberg's Bluegrass. Journal of Range Management 43:506-513.

Link, S. O., G. W. Gee, M. E. Thiede, and P. A. Beedlow. 1990b. Response of a Shrub-Steppe Ecosystem to Fire: Soil Water and Vegetational Change. Arid Soils Research and Rehabilitation $4: 163-172$.

Link, S. O., J. L. Downs, M. E. Thiede, D. J. Lettau, T. R. Twaddell, and R. A. Black. $1992 a$. Evapotranspiration Studies for Protective Barriers: FY 1990 Status Report. PNL-8032, Pacific Northwest Laboratory, Richland, Washington.

Link, S. O., M. E. Thiede, J. L. Downs, D. J. Lettau, and W. J. Waugh. 1992b. Evapotranspiration Studies for Protective Barriers: FY 1989 Status Report. PNL-8033, Pacific Northwest Laboratory, Richland, Washington.

Link, S. O., R. N. Kickert, M. J. Fayer, and G. W. Gee. 1993. A Comparison of Simulation Models for the Prediction of Soil Water Dynamics in Bare and Vegetated Lysimeters. PNL-8675, Pacific Northwest Laboratory, Richland, Washington.

Link, S. O., W. J. Waugh, and J. L. Downs. 1994a. The Role of Plants on Isolation Barriers Systems. In In Situ Remediation: Scientific Basis for Current and Future Technologies, eds. G. W. Gee and N. R. Wing, pp. 561-592. Proceedings of the 33rd Hanford Symposium on Health and Environment, Pasco, Washington, November 7-11, 1994. Battelle Press, Columbus, Ohio. 
Link, S. O., L. L. Cadwell, C. A. Brandt, J. L. Downs, R. E. Rossi, and G. W. Gee. 1994b. Biointrusion Test Plan for the Permanent Isolation Surface Barrier Prototype. PNL-9411, Pacific Northwest Laboratory, Richland, Washington.

Link, S. O., W. J. Waugh, J. L. Downs, M. E. Thiede, J. C. Chatters, and G. W. Gee. 1994c. Effects of Coppice Dune Topography and Vegetation on Soil Water Dynamics in a Cold-Desert Ecosystem. Journal of Arid Environments 27:265-278.

Link, S. O., M. E. Thiede, R. D. Evans, J. L. Downs, and G. W. Gee. 1995a. Responses of Big Sagebrush and Spiny Hopsage to Increasing Seasonal Drought. In Proc. Conf. Shrub Research Consortium, U.S. Forest Serv. Interm. Res. Stan. Gen. Tech. Rep. pp. 196-201.

Link, S. O., H. Bolton, Jr., M. E. Thiede, and W. H. Rickard. 1995b. Responses of Downy Brome to Nitrogen and Water. Journal of Range Management 48:290-297.

Mack, R. N., and J. N. Thompson. 1982. Evolution in Steppe with Few Large, Hooved Mammals. American Naturalist 119:757-773.

Marks, D., G. A. King, and J. Dolph. 1993. Implication of Climate Change for the Water Balance of the Columbia River, USA. Climate Research 2:203-193.

Marshall, J. K. 1972. Principles of Soil Erosion and its Prevention. In The Use of Trees and Shrubs in the Dry Country of Australia. ed. N. Hall, pp. 90-107. Australian Government Publishing Service, Canberra, Australia.

Melgoza, G., R. S. Nowak, and R. J. Tausch. 1990. Soil Water Exploitation After Fire: Competition Between Bromus tectorum and Two Native Species. Oecologia 83:7-13.

Mehringer, P. J., Jr. 1985. "Late Quaternary Pollen Records from the Interior Pacific Northwest and Northern Great Basin of the United States." In Pollen Records of Late-Quaternary North American Sediments, eds. V. M. Bryant, Jr. and R. G. Holloway, pp. 167-189. American Association of Stratigraphic Association, Dallas, Texas.

Muhs, D. R., and P. B. Maat. 1993. The Potential Response of Eolian Sands to Greenhouse Warming and Precipitation Reduction on the Great Plains of the U.S.A. Journal of Arid Environments 25:351-361.

Nyhan, J. W. 1989. Development of Technology for the Long-Term Stabilization and Closure of Shallow Land Burial Sites in Semiarid Environments. LA-1128-MS, Los Alamos National Laboratory, Los Alamos, New Mexico.

O'Farrell, T. P., and R. O. Gilbert. 1975. Transport of Radioactive Materials by Jackrabbits on the Hanford Reservation. Health Physics 29:9-15. 
Pearson, L. C. 1975. Daily and Seasonal Patterns of Photosynthesis in Artemisia tridentata. Journal of the Idaho Academy of Science 11:11-19.

Petersen, K. L., J. C. Chatters, and W. J. Waugh. 1993. Long-Term Climate Change Assessment Study Plan for the Hanford Site Permanent Isolation Barrier Development Program. WHC-EP-0569, Revision 1, Westinghouse Hanford Company, Richland, Washington.

Price, K. R. 1973. Tumbleweed and Cheatgrass Uptake of Transuranium Elements Applied to Soil as Organic Acid Complexes. BNWL-1755, Battelle Pacific Northwest Laboratories, Richland, Washington.

Price, K. R., and W. H. Rickard. 1973. Vascular Plants of Waste Storage Sites in the 200 Areas of the Hanford Reservation. BNWL-1796, Battelle Pacific Northwest Laboratories, Richland, Washington.

Pyke, C. B. 1972. Some Meteorological Aspects of the Seasonal Distribution of Precipitation in the Western United States and Baja California. Water Resources Center Contribution No. 139. University of California, Los Angeles, California.

Quinn, R. S. 1976. The Late Spring Secondary Precipitation Maximum in the Interior Pacific Northwest. Ph.D. Dissertation, University of Oregon, Corvalis. University Microfilms International, Ann Arbor, Michigan.

Richards, L. A. 1950. Laws of Soil Moisture. Transactions of the American Geophysical Union 31:750-756.

Rickard, W. H., D. W. Uresk, and J. F. Cline. 1977. Productivity Response to Precipitation by Native and Alien Plant Communities. In Proceedings of the Symposium on Terrestrial and Aquatic Ecological Studies of the Northwest. eds. R. D. Andrews, R. L. Carr, F. Gibson, B. Z. Lang, R. A. Soltero, and K. C. Swenberg, March 26-27, 1976. EWSC Press, Eastern Washington State College, Cheney, Washington.

Rickard, W. H., and R. H. Sauer. 1982. Self Revegetation of Disturbed Ground in the Deserts of Nevada and Washington. Northwest Sci. 56:41-47.

Rickard, W. H. 1988. Climate of the Hanford Site. In Shrub-Steppe: Balance and Change in a SemiArid Terrestrial Ecosystem. eds. W. H. Rickard, L. E. Rogers, B. E. Vaughan, and S. F. Liebetrau, pp. 23-59. Elsevier, Amsterdam.

Rickard, W. H., and C. A. Schuler. 1988. Descriptions of Plant Communities at the Proposed Reference Repository Location and Implications for Reclamation of Disturbed Ground. PNL-6494, Pacific Northwest Laboratory, Richland, Washington. 
Rickard, W. H., L. E. Rogers, B. E. Vaughan, and S. F. Liebetrau, eds. 1988. Shrub-Steppe: Balance and Change in a Semi-Arid Terrestrial Ecosystem. Elsevier, Amsterdam.

Rickard, W. H., and B. E. Vaughan. 1988. Plant Community Characteristics and Responses. In Shrub-Steppe: Balance and Change in a Semi-Arid Terrestrial Ecosystem. eds. W. H. Rickard, L. E. Rogers, B. E. Vaughan, and S. F. Liebetrau, pp. 109-179. Elsevier, Amsterdam.

Risser, P. G., E. C. Birney, H. D. Blocker, S. W. May, W. J. Parton, and J. A. Weins. 1981. The True Prairie Ecosystem. Hutchinson Ross Publishing Company, Stroudsburg, Pennsylvania.

Roché, C. T., and B. F. Roché. 1988. Distribution and Ecologic Amplitude of Selected Centaurea Species in Eastern Washington. Northwest Sci. 62:242-253.

Rockhold, M. L., M. J. Fayer, G. W. Gee, and M. J. Kanyid. 1990. Natural Groundwater Recharge and Soil-Water Balance at the Hanford Site. PNL-7215, Pacific Northwest Laboratory, Richland, Washington.

Rogers, L. E., and W. H. Rickard. 1977. Ecology of the 200 Area Plateau Waste Management Environs: A Status Report. PNL-2253, Pacific Northwest Laboratory, Richland, Washington.

Routson, R. C. 1975. The Effect of Soil Concentration on the Tumbleweed Uptake of ${ }^{90} \mathrm{Sr}$ and ${ }^{137} \mathrm{Cs}$ from a Burbank Sand. BNWL-1905, Battelle, Pacific Northwest Laboratories, Richland, Washington.

Routson, R. C., M. R. Fuchs, and W. A. Jordan. 1988. Recharge Estimate for the Hanford Site 200 Areas Plateau. WHC-EP-0046, Westinghouse Hanford Company, Richland, Washington.

Routson, R. C., and V. G. Johnson. 1990. Recharge Estimates for the Hanford Site 200 Areas Plateau. Northwest Science 64:150-158.

Ruffner, J. A., and F. E. Bair. 1977. The Weather Almanac, 2nd edition. Gale Research Company, Book Tower, Detroit, Michigan.

Sackschewsky, M. R., J. C. Chatters, S. O. Link, and C. A. Brandt. 1991. Protective Barrier Program: Test Plan for Plant Community Dynamics. WHC-EP-0380, Westinghouse Hanford Company, Richland, Washington.

Sackschewsky, M. R., D. S. Landeen, G. I. Baird, W. H. Rickard, and J. L. Downs. 1992. Vascular Plants of the Hanford Site. WHC-EP-0554, Westinghouse Hanford Company, Richland, Washington.

Sackschewsky, M. R., C. J. Kemp, and L. L. Cadwell. 1993. Status Report for the Small-Tube Lysimeter Facility Fiscal Year 1992. WHC-EP-0597, Westinghouse Hanford Company, Richland, Washington. 
Sackschewsky, M. R., C. J. Kemp, S. O. Link, and W. J. Waugh. 1995. The Effects of Engineered Soil Surfaces on Soil Water Budgets in a Cool Desert Environment. Journal of Environmental Quality 24:352-359.

Schneider, S. H. 1989. Global Warming. Sierra Club Books, San Francisco, California.

Selders, A. A. 1950. The Absorption and Translocation of Fission Elements by Russian Thistle. HW-18034, General Electric Company, Richland, Washington.

Shuman, R. 1984. Intrusion of Soil Covered Uranium Mill Tailings by Whitetail Prairie Dogs and Richardson's Ground Squirrels. M. S. Thesis. Colorado State University, Fort Collins, Colorado.

Skaggs, R. L., and L. L. Cadwell. 1988. Processes Controlling Surface Water Distribution in the Shrub-Steppe. In Pacific Northwest Laboratory Annual Report for 1987 to the DOE Office of Energy Research. Part 2. Environmental Sciences, ed. R..E. Wildung, pp. 8-9. PNL-6500 Pt. 2, Pacific Northwest Laboratory, Richland, Washington.

Stone, W. A., J. M. Thorp, O. P. Gifford, and D. J. Hoitink. 1983. Climatological Summary for the Hanford Area. PNL-4622, Pacific Northwest Laboratory, Richland, Washington.

Sturges, D. L. 1979. Hydrologic Relation of Sagebrush Lands. In The Sagebrush Ecosystem: $A$ Symposium, April 1978, pp. 86-100. College of Natural Resources, Utah State University, Logan.

Suter II, G. W., R. J. Luxmoore, and E. D. Smith. 1993. Compacted Soil Barriers at Abandoned Landfill Sites are Likely to Fail in the Long Term. Journal of Environmental Quality 22:217-226.

Tchoupopnou, E. 1989. Splash from Microphytic Soil Crusts Following Simulated Rain. M. Sc., Utah State University, Logan, Utah.

Thompson, R. S., C. Whitlock, P. J. Bartlein, S. P. Harrison, and W. G. Spaulding. 1993. Climatic Changes in the Western United States since 18,000 yr B.P. In Global Climates Since the Last Glacial Maximum, eds. H. E. Wright, Jr., J. E. Kutzbach, T. Webb III, W. F. Ruddiman, F. A. Street-Perrott, and P. J. Bartlein, pp. 468-513. University of Minnesota Press, Minneapolis.

Uresk, D. W., J. F. Cline, and W. H. Rickard. 1979. Growth Rates of a Cheatgrass Community and Some Associated Factors. Journal of Range Management 32:168-170.

Voorhees, L. D., M. J. Sale, J. W. Webb, and P. J. Mulholland. 1983. Guidance for Disposal of Uranium Mill Tailings: Long-Term Stabilization of Earthen Cover Materials. NUREG/CR-3199, Oak Ridge National Laboratory, Oak Ridge, Tennessee. 
Walters, W. H., and B. G. Gilmore. 1993. Water Erosion. In Hanford Site Protective Barrier Development Program: Fiscal Year 1992 and 1993 Highlights. eds., L. L. Cadwell, S. O. Link, and G. W. Gee, pp. 2.22-2.23. PNL-8741, Pacific Northwest Laboratory, Richland, Washington.

Waugh, W. J., and S. O. Link. 1988. Barrier Erosion Control Test Plan: Gravel Mulch, Vegetation, and Soil Water Interactions. WHC-EP-0067, Westinghouse Hanford Company, Richland, Washington.

Waugh, W. J., M. E. Thiede, L. L. Cadwell, G. W. Gee, H. D. Freeman, M. R. Sackschewsky, and J. F. Relyea. 1991. Small Lysimeters for Documenting Arid Site Water Balance. In Proceedings of the International Symposium on Lysimetry. ed. R. G. Allen, pp. 151-159. Amer. Soc. Civil Engr., New York.

Waugh, W. J., J. C. Chatters, G. V. Last, B. N. Bjornstad, S. O. Link, and C. R. Hunter. 1994a. Barrier Analogs: Long-Term Performance Issues, Preliminary Studies, and Recommendations. PNL-9004, Pacific Northwest Laboratory, Richland, Washington.

Waugh, W. J., K. L. Peterson, S. O. Link, B. N. Bjornstad, and G. W. Gee. 1994b. Natural Analogs of the Long-Term Performance of Engineered Covers. In In Situ Remediation: Scientific Basis for Current and Future Technologies, eds. G. W. Gee and N. R. Wing, pp. 379-409. Proceedings of the 33rd Hanford Symposium on Health and Environment, Pasco, Washington, November 7-11, 1994. 'Battelle Press, Columbus, Ohio.

Waugh, W. J., M. E. Thiede, D. J. Bates, L. L. Cadwell, G. W. Gee, and C. J. Kemp. 1994c. Plant Cover and Water Balance in Gravel Admixtures at an Arid Waste-Burial Site. Journal of Environmental Quality 23:676-685.

West, N. E. 1979. Basic Synecological Relationships of Sagebrush-Dominated Lands in the Great Basin and the Colorado Plateau. In The Sagebrush Ecosystem: A Symposium, April 1978, pp. 33-41. College of Natural Resources, Utah State University, Logan, Utah.

West, N. E. 1990. Structure and Function of Microphytic Soil Crusts in Wildland Ecosystems of Arid and Semi-Arid Regions. Advances in Ecological Research 20:179-223.

Wing, N. R. 1992. A Peer Review of the Hanford Site Permanent Isolation Surface Barrier Development Program. WHC-MR-0392, Westinghouse Hanford Company, Richland, Washington.

Wing, N. R., and G. W. Gee. 1993. The Development of Permanent Isolation Surface Barriers: Hanford Site, Richland, Washington. In Geoconfine 93. eds. M. Amould, M. Barrès \& B. Côme, pp. 357-362. Balkema, Rotterdam. 
Winograd, I. J., T. B. Coplen, J. M. Landwehr, A. C. Riggs, K. R. Ludwig, B. J. Szabo, T. P. Kolesar, and M. Revesz. 1992. Continuous 500,000-Year Climate Record from Vein Calcite in Devils Hole, Nevada. Science 258:255-260.

Winsor, T. F., and F. W. Whicker. 1980. Pocket Gophers and Redistribution of Plutonium in Soil. Health Physics 39:257-262. 


\section{Distribution}

No. of

Copies

\section{OFFSITE}

C. S. Abrams

Argonne National Laboratory

P.O. Box 2528

Idaho Falls, ID 83401

J. Anderson

Idaho State University

Department of Biology

Pocatello, ID 83209

2 Battelle Memorial Institute

Project Management Division

505 King Avenue

Columbus, $\mathrm{OH} 43201$

ATTN: W. A. Carbeiner

Technical Library

M. Benge

Bechtel-FUSRAP

P.O. Box 350

Oak Ridge, TN 37830

R. D. Bennett

U.S. Army Engineer Waterways

Experiment Station

3909 Halls Ferry Road

Vicksburg, MS 39180-6199

B. Bede

U.S. Ecology

509 E. 12th

Olympia, WA 98501

R. A. Black

Washington State University

Botany Department

Pullman, WA 99164
No. of

Copies

R. R. Borish

West Valley Nuclear Service Company

P.O. Box 191

West Valley, NY 14171

4 Chem Nuclear Geotech

P.O. Box 14000

Grand Junction, CO 81502

ATTN: W. J. Waugh

A. T. Clark

U.S. Nuclear Regulatory Commission

Division of Fuel Material Safety

Washington, D.C. 20555

D. E. Daniel

University of Texas

Dept. of Civil Eng.

Austin, TX 78712

3 Desert Research Institute

P.O. Box 60220

Reno, NV 89506

ATTN: J. T. Ball

S. W. Tyler

C. Fox

M. Dunkelman

Department of Health

Division of Radiation Protection

Airdustrial Park

Bldg. 5, M.S. LE-13

Olympia, WA 98504

2 Foster Wheeler Environ.

1981 Snyder Rd.

Richland, WA 99352

ATTN: W. Riggsbee

R. L. Treat 
No. of

Copies

2 Environmental Protection Agency

Hanford Project Office

712 Swift, MS B5-01

Richland, WA 99.352

ATTN: D. A. Faulk

P. S. Innis

\section{S. Evans}

U.S. Department of Energy

1580 Sawtelle Drive

Idaho Falls, ID 83403

L. G. Everett

Geraghty \& Miller, Inc.

5425 Hollister Ave., Suite 100

Santa Barbara, CA 93111-2346

F. T. Fong

U.S. Department of Energy

San Francisco Operations Office

1333 Broadway

Oakland, CA 94612

2 Hill Air Force Base

Environmental Management

Directorate

OO-ALC/EM

7276 Wardleigh Road

Hill AFB, UT 84056-5127

ATTN: B. Elliot

D. Stone

R. G. Hills

Department of Mechanical Eng.

New Mexico State University

Box 30001

La Cruces, NM 88003
No. of

Copies

7 Idaho National Engineering Laboratory

P.O. Box 1625

Idaho Falls, ID 83415

ATTN: J. E. Conner

J. Hubbell

M. A. Knecht

K. M. Kostelnik

D. L. McElroy

J. B. Sisson

Technical Library

4 Jacobs Engineering Group, Inc.

2155 Louisiana Blvd. NE \#1000

Albuquerque,.NM 87110-5414

ATTN: T. Goering

M. Kyllo

J. Lommler

F. Titus

T. L. Jones

New Mexico State University

Agricultural Experiment Station

Box 3BF

Las Cruces, NM 88003

M. R. Jugan

U.S. Department of Energy

Oak Ridge Operations Office

P.O. Box $\dot{\mathrm{E}}$

Oak Ridge, TN 37830

W. A. Jury

University of California

at Riverside

Dept. of Soils

Riverside, CA 92502

D. Keefer

Illinois State Geological Survey

615 East Peabody Drive

Champaign, IL 61820 
No. of

Copies

C. Keller

SNL, Eastman Cherrington

P.O. Box 10129

Santa Fe, NM 87504

D. A. Knecht

Westinghouse Idaho Nuclear Co.

P.O. Box 4000

Idaho Falls, ID 83403

R. C. Letcher

U.S. Department of Energy

Morgantown Energy Technology Center

P.O. Box 880

Morgantown, WV 26505

4 Los Alamos National Laboratory

P.O. Box 1663

Los Alamos, NM 87545

ATTN: F. Barnes

K. V. Bostick

J. W. Nyhan

E. Springer

E. Maestas

U.S. Department of Energy

West Valley Project Office

P.O. Box 191

West Valley, NY 14171

C. Mascarenas

WINCO

P.O. Box 4000, MS 1572

Idaho Falls, ID 83404

C. Massimino

U.S. Environmental Protection

Agency

1200 Sixth Avenue

Seattle, WA 98101

S. Needler

EG\&G, Rock Flats

P.0. Box 464, Building 080

Golden, CO 80402
No. of

Copies

4 Oak Ridge National Laboratory

P.O. Box 2008

Oak Ridge, TN 37831

ATTN: G. Suter II

J. Kuhaida

R. J. Luxmoore

M. Marietta

2 Oak Ridge National Laboratory

P.O. Box Y

Oak Ridge, TN 37830

ATTN: W. D. Burch

R. T. Jubin

D. T. Oakley

Waste Policy Institute

555 Quince Orchard Road

Suite 600

Gaithersburg, MD 20878

K. L. Petersen

207 Benham Street

Richland, WA 99352

C. Reith

15 Rue LeMans

Kenner, LA 70065

J. Rensel, MS PV-11

Washington State Department of Ecology

High-Level Waste Management

Olympia, WA 98504

G. N. Richardson

Hazen and Sawyer

4011 W. Chase Blvd.

Suite 500

Raleigh, NC 27607

2 Sandia National Laboratories

P.O. Box 5800

Albuquerque, NM 87185

ATTN: R. W. Lunch

Technical Library 
No. of

Copies

B. Scanlon

Bureau of Economic Geology

University of Texas at Austin

University Station, Box X

Austin, TX 78713-7508

J. A. Shaffner

US Ecology

3855 Atherton Road

Suite 5

Rocklin, CA 95765

R. Shaw

Electric Power Research

Institute

3412 Hillview Avenue

Palo Alto, CA 94304

S. D. Smith

University of Nevada-Las Vegas

Biology Department

Las Vegas, NV 89154

W. G. Spaulding

Dames and Moore

Suite 108

4220 S. Maryland Parkway

Las Vegas, NV 89119

M. J. Steindler

Argonne National Laboratory

9700 South Cass Avenue

Argonne, IL 60439

J. B. Stong

Gonzaga University

Civil Engineering Dept

E. 502 Boone

Spokane, WA 99258-0001

M. J. Sully

Reynolds Electric Engr.

Co. Inc., MS 966

2626 Losee Road

Las Vegas, NV 89030
No. of

Copies

2 U.S. Department of Energy-

Albuquerque Operations Office

P.O. Box 5400, MS ERPO

Albuquerque, NM 87185-5400

ATTN: K. Bitner

G. J. Rael

3 U.S. Department of Energy

785 DOE Place

Idaho Falls, ID 83402

ATTN: O. D. Markham

R. C. Morris

T. E. Reynolds

2 U.S. Department of Energy

Savannah River Operations Office

P.O. Box A

Aiken, SC 29801

ATTN: W. J. Brumley

D. Bruegennjohann

2 U.S. Ecology

5333 Westheimer Rd.

Suite 1000

Houston, TX 77056-5407

ATTN: A. Palmer

L. D. Irwin

2 U.S. Geological Survey

$333 \mathrm{~W}$. Nye Lane

Carson City, NV 89706

ATTN: B. J. Andraski

D. E. Prudic

2 U.S. Geological Survey

Low-Level Radioactive Waste

Program

Water Resources Division

12201 Sunrise Valley Drive

Reston, VA 22092

ATTN: N. Trask

I. Winograd 
No. of

Copies

3 U.S. Geological Survey

1201 Pacific Ave., Suite 600

Tacoma, WA 98402

ATTN: W. R. Bidlake

B. W. Drost

E. A. Prych

2 U.S. Nuclear Regulatory

Commission

Division of Engineering Safety

Waste Management Branch

5650 Nicholson Lane

Rockville, MD 29852

ATTN: T. J. Nicholson

E. O'Donnell

2 Washington State Department

of Ecology

7601 W. Clearwater, Suite 102

Kennewick, WA 99336

ATTN: D. Teal

N. Uziemblo

3 Washington State Department of Ecology

Mail Stop PV-11

Olympia, WA 98504-8711

ATTN: E. M. Carlin

C. Cline

R. B. Hibbard

5 Washington State University

Geology Department

Pullman, WA 99164

ATTN: A. J. Busacca

G. S. Campbell

D. Gaylord

K. Keller

P. J. Mehringer

E. P. Weeks

U.S. Geological Survey

Federal Center Mail Stop 413

Denver, CO 80225
No. of

Copies

M. Weishan

NYSERDA

P.O. Box 191

West Valley, NY 14171

10 Westinghouse Savannah River Company

P.O. Box 616

Aiken, SC 29802

ATTN: J. Cook

M. Flora

L. Huber

J. R. Knight

S. R. McMullin

E. Norton

M. J. Plodinec

C. T. Randall

E. Schiefer

M. G. Serrato

P. J. Wierenga

University of Arizona

Dept. of Soil \& Water

429 Shantz Building

Tucson, AZ 85721

\section{FOREIGN}

Prof. Johann Korkisch

Institute of Analytical Chemistry

University of Urnna

A-1090 Vienna

Wahringerstrasse 38

AUSTRIA

S. Melchior

Institut für Bodenkunde der

Universität Hamburg

Allende-Platz 2, D-2000

Hamburg 13

FEDERAL REPUBLIC OF GERMANY 
No. of

Copies

G. M. Smith

Intera Information Technologies

Chiltern House

45 Station Road

Henley-on-Thames

Oxfordshire RG9 1AT

UNITED KINGDOM

\section{ONSITE}

13 DOE Richland Operations Office
J. J. Broderick
A7-27
B. L. Foley
H4-83
R. D. Freeberg
A5-19
R. E. Gerton
A4-02
J. D. Goodenough
J. P. Hanson
A5-19
K8-50
R. A. Holten
$\mathrm{H} 4-83$
R. D. Izatt
A3-42
P. M. Pak
A5-19
R. K. Stewart
A5-19
D. E. Trader
A5-90
D. D. Wodrich
S7-50

DOR-RL Reading Room 1

1 U.S. Army Corps of Engineers

W. L. Greenwald A5-20

11 Bechtel Hanford Incorporated
M. A. Buckmaster H6-01
R. A. Carlson
H6-05
F. M. Corpuz
H4-85
T. A. Curran
H6-01
H. D. Downey H4-84
C. E. Hodge H4-82
M. J. Lauterbach H4-91
D. R. Myers H4-82
S. R. Weil H4-79
T. M. Wintczak H4-92
J. G. Woolard H4-89

No. of

Copies

4 Kaiser Engineers Hanford Company

C. C. Chamberlain G3-09

S. D. Consort E6-31

D. L. Fort E6-50

R. I. Watkins E6-41

19 Westinghouse Hanford Company

M. R. Adams H6-30

R. J. Bliss B3-04

G. W. Jackson H6-71

K. N. Jordan S7-83

M. K. Korenko B4-03

R. E. Lerch S7-85

H. E. McGuire B3-63

D. J. Newland T7-37

R. W. Powell G3-21

R. C. Roos H6-30

W. A. Skelly L4-69

J. C. Sonnichsen H6-23

A. M. Tallman H6-30

J. A. Voogd G6-13

G. F. Williamson G6-13

R. D. Wojtasek S7-84

D. E. Wood H6-30

Environmental Data Management

Center (2)

38 Pacific Northwest Laboratory

K. A. Blanchard K2-05

L. L. Cadwell K6-84

R. S. Davis K9-33

J. L. Downs K6-84

M. J. Fayer K9-33

D. Felmy K9-33

H. D. Freeman P8-38

G. W. Gee K9-33

B. G. Gilmore K9-33

P. C. Hays K9-33 
No. of

Copies

$\begin{array}{ll}\text { C. T. Kincaid } & \text { K9-33 } \\ \text { R. R. Kirkham } & \text { K9-33 } \\ \text { G. V. Last } & \text { K9-48 } \\ \text { M. W. Ligotke } & \text { P7-59 } \\ \text { S. O. Link (10) } & \text { K6-84 } \\ \text { P. D. Meyer } & \text { K9-33 } \\ \text { T. L. Page } & \text { K9-18 }\end{array}$

No. of

Copies
M. L. Rockhold
K9-33
R. A. Romine
P8-38
E. J. Rykiel
K6-84
M. R. Sackschewsky K6-84
A. L. Ward
K9-33
Information Release (7) 